\title{
The Emotions of Top Managers and Key Persons in Cross-Border M\&As: Evidence from a longitudinal case study
}

\begin{abstract}
Building on prior research on emotions in $\mathrm{M} \& \mathrm{~A}$, this paper analyses the post-M\&A emotions of top managers and key persons from the acquired company by examining what triggers emotions during the post-acquisition integration stage, and what the consequences of those emotions are. This study applies cognitive appraisal and affective event theories with empirical evidence based on a longitudinal, single case study of an Indian-Finnish acquisition. The main findings imply that M\&As are very emotional for top managers and key persons. Our findings reveal that they experience a wide range of positive and negative emotions triggered by individual and company-level triggers. Interestingly various triggers can have different and opposite appraisal outcomes in the short and long-term. In addition, top managers and key persons are often restricted in the range of behavioural outcomes caused by emotions.
\end{abstract}

Keywords: emotions, cross-border mergers and acquisitions, post-M\&A integration, top managers, cognitive appraisal theory, affective event theory 


\section{Introduction}

Cross-border mergers and acquisitions (M\&As) have become increasingly popular as a means of organisational growth and internationalisation. However, studies suggest that acquisition success rate has remained mediocre at best (e.g. King, Dalton, Daily, \& Covin, 2004; Schoenberg, 2006). Cultural diversity, and organisational and cultural incompatibility (i.e. a lack of organisational and cultural fit) is often reported as the main cause for poor acquisition performance (cf. Cartwright \& Schoenberg, 2006; Stahl \& Voigt, 2008; Teerikangas \& Joseph, 2012). Consequently, research on socio-cultural integration in M\&As has largely focused on acquired employees' negative emotions and attitudes, and on the "merger syndrome" as a typical post-merger phenomenon (e.g. Kusstatscher \& Cooper, 2005; Marks \& Mirvis, 2001; Sinkovics, Zagelmeyer, \& Kusstatscher, 2011). Yet, M\&As evoke a wide range of emotions in both employees and top managers (e.g. Kiefer, 2002; Kusstatscher \& Cooper, 2005; Kusstatscher, 2006). It has been suggested that emotions provide a critical "missing" socio-cultural mechanism that connects many of the key aspects discussed in the "human" literature (Sarala, Vaara, \& Junni, in press). This research contributes to the postM\&A socio-cultural integration research by focusing on a wide range of emotions, positive and negative emotions, experienced by top managers and key persons.

Emotions have been of scholarly interest for decades in disciplines such as psychology, sociology, communication studies, anthropology, management and marketing (cf. Kusstatscher \& Cooper, 2005). Interest in emotion research is relatively recent among business scientists, only having started in the last twenty years (cf. Ashkanasy \& Humphrey, 2011). In international business (IB), research on emotions is still scarce. Whilst emotions have been bypassed in much of the previous M\&A research, some studies have placed emotions in the spotlight. Prior M\&A research focusing on emotions has focused on the role of emotions in M\&As (Kusstatscher \& Cooper, 2005; Kusstatscher, 2006; Sinkovics et al. 
2011), the emotional experience of employees during organisational change (Ager, 2011; Kiefer, 2002), employee emotional resilience during post-M\&A integration (Khan, Soundararajan, Wood \& Ahammad, in press), the role of management communication and other factors on emotions of employees (Gunkel, Schlaegel, Rossteutscher, \& Wolff, 2015; Zagelmeyer, Sinkovics, Sinkovics, \& Kusstascher, 2016), the role of culture in emotional attendance (Reus, 2012) and how employees manage their emotions (Clarke \& Salleh, 2011). Few studies focus on managers; Vince (2006) analyses managers' emotions and rationalizations during M\&As, Reus (2012) explored acquirers' emotional attending during cross-border M\&A, and Durand (2016) focuses on middle managers and demonstrates the relevance of critical incident technique to assess managerial perceptions, emotions and stress in post-M\&A stage. There is a research gap regarding top managers individual level emotional experience during post-M\&A integration.

With this research we aim to identify and describe the emotional experience of acquired top managers and key persons following an M\&A. In this study we conceptualise emotional experience following Kiefer (2002) definition: "emotional experience describes the emotions and related cognitions and behaviours surrounding events during change" (p. 40). According to Kiefer (2002), the continuous experience of different emotions over time, connected with the interpretation of ongoing events, form the individual experience of change. Hence, the individual experience of an M\&A is part of a complex set of interdependent emotions. Key persons are defined as those managers and/or employees in the acquired organisation who are critical for ensuring the success of the acquisition and the continuity of business in the acquired organisation (Ranft \& Lord, 2002).

A deeper and more comprehensive understanding of the post-M\&A emotions of top managers and key persons is critical for many reasons. Firstly, employees tend to mirror their managers' emotions (Ashkanasy \& Daus, 2002). Managers and key persons, whether staying 
or leaving post-M\&A, can have a significant influence on the atmosphere and the affective experience of an M\&A (cf. Gooty, Connelly, Griffith, \& Gupta, 2010; Kaplan et al., 2014; Krug \& Hegarty, 2001; Kusstastcher, 2006). This is particularly important from an "emotional contagion" perspective; in organisations, emotions are shared and groups may experience collective emotions (cf. Barsade, 2002; Elfenbein, 2014). Secondly, emotions are triggered because of something, vary in intensity and tend to lead to behavioural outcomes (Frijda, 1993; Larsen, Augustine, \& Prizmic, 2009; Rank \& Frese, 2008; Solomon, 2008). Previous studies indicate that employees' emotions influence their willingness to contribute towards successful post-M\&A integration (e.g. Kusstatscher, 2006), thus it seems reasonable to assume that this is also the case for top and middle managers and other key persons. If so, they can considerably influence the integration process of the whole merging organisation. Understanding the emotional experience of top managers and key persons during this difficult period might shed some light on how to retain key managers. The top management in the acquired organisation is often replaced shortly after the acquisition (Jagersma, 2005), yet often, retaining them is considered valuable (Angwin \& Meadows, 2014), especially when the acquirer is unfamiliar with the business and/or the external business environment.

Accordingly, the purpose of our study is two-fold: to explore what emotions top managers and key persons experience during the post-M\&A integration stage, and what the emotional experience of top managers and key persons during the post-M\&A integration stage is. Consequently, our main argument is that understanding the post-M\&A emotional experiences of top managers and key persons is essential to the successful management of the post-M\&A integration stage. Moreover, in cross-border M\&As, emotions are managed from a distance and cultural differences add an additional challenge to managing emotions; identifying points of stress and choosing effective managers to implement the M\&A (Sinkovics et al., 2011). The M\&A process can be divided into two main stages, namely pre- 
and post-M\&A stage (cf. Jemison \& Sitkin, 1986; Haspeslagh \& Jemison, 1991). This research focuses on the post-M\&A stage for two reasons: 1 . access to data is easier once the deal has been completed and has been announced, and 2. emotions tends to be higher after the deal due to completion of the deal and the complexity of the integration stage. This research is a fine-grained temporal analysis of emotions during the post-M\&A integration stage, which forms the temporal context of this research (cf. Tian, Nicholson, Eklinder-Frick \& Johanson, in press).

This study applies cognitive appraisal and affective event theories. Our study is inspired by Kiefer's (2002) research on emotional experience during M\&A, and builds on and extends the work by Kusstatscher and Cooper (2005) and Sinkovics et al. (2011). Our study contributes by focusing on the emotions of top managers and key persons, by exploring more broadly the various triggers/antecedents to emotions, and by adopting a longitudinal approach, which enables us to focus on emotional experiences for two years during the postM\&A integration process. The empirical research is based on a longitudinal, single case of an Indian-Finnish acquisition in the IT field. This research focuses on the acquired firm. The underlying assumption is that emotions tend to run much higher in acquired organisations, as managers must adapt to a new owner, management style, and organisational culture. Understanding acquired top managers' and key persons' emotions is particularly important in strategic and/or unrelated as well as international M\&As, in which there is a greater need to retain and rely on local acquired top managers and key persons to achieve synergies. Prior research suggests that acquired subsidiaries are promising sources of reverse knowledge transfer (Mudambi, Piscitello \& Rabbiosi, 2014) and that acquired subsidiaries located in more developed countries, such as those in the Western Europe, are more likely to transfer knowledge to the headquarters (Rabbiosi, 2011). Cross-border M\&As involving emerging economies, especially China and India, have increased dramatically during the past decade 
(e.g. World Investment Report, 2017), rendering this case study an appropriate context in which to study emotions.

This paper is organised as follows. First, we define emotions and develop the theoretical background to emotional reactions during post-M\&A integration stage. We then introduce our case study and the research methodology. In the third section, we present our main findings. Finally, we discuss our contributions, limitations and conclusions. This paper contributes to the M\&A and emotion literature by focusing on the role of emotions in more fine-grained way, and by demonstrating the dynamic nature of the emotional experience of top managers and key persons during the post-M\&A integration stage (see e.g. Sarala, Vaara \& Junni, in press).

\section{Discussion of prior literature and analytical framework}

\subsection{Emotions and theories about emotions}

Within emotion literature emotions are seldom explicitly defined (Gooty et al. 2009). For example, mood, feelings and emotions are often used interchangeably. Moods refer to a longer time spans than emotions, and to the larger, pervasive, existential issues of one's life than acute emotions (Lazarus 1991, 48). Feelings refer to the awareness of bodily sensations, while emotions refer to situations when there has been an (immediate) appraisal of harm or benefit (Lazarus 1991, 57). Philosophers often distinguish between occurrents (emotion episodes) and endurants (states, mood). Being in a state of sadness, or in a mood of melancholy can be endurant, continuous. Arousal is often categorized as a state, and to distinct between arousal and emotions, it is argued that arousal may carry on, endure, after an emotion has occurred. (Mulligan \& Scherer, 2012.) We make a distinction between emotions and moods/feelings, and concentrate on emotions that are short-term and more easily identifiable to certain triggers and outcomes (Frijda, 1993). 
Following Kusstatscher and Cooper (2005, p. 48) and Sinkovics et al. (2011, p. 28), we define emotions as "a mental state of (action) readiness that arises from cognitive appraisals of events, social interaction of thoughts. It has a phenomenological tone, is accompanied by physiological processes, and is often expressed physically" (see Bagozzi, Gobinath, \& Nyer, 1999). Emotions are focused on concrete events, objects and situations and last a relatively short time (Mulligan \& Scherer, 2012). Emotions are not continuous, but episodic. For example, the death of a loved one triggers numerous episodes of feeling sad about loss, and may consists of short periods of relieved emotions. Nonetheless, the emotions themselves do not continue, only the feeling. (Mulligan \& Scherer, 2012.) Emotion episodes are used in emotion literature to refer to the experience of a single emotion including its duration and intensity (see e.g. Lazarus, 1991; Scherer 2009; Verduyn, Mechelen, Tuerlinckx, Meers and Van Coillie, 2009). Episodes refer to short temporal periods, which are non-sequential (cf. Holmlund, 2004; Tian et al., in press).

There are various categorisations of emotions (e.g. Laros \& Steenkamp, 2005; Lazarus, 1993) but in organisation studies they are often divided into four positive (contentment, happiness, affection (love) and pride) and four negative (anger, fear, sadness and shame) basic emotions (e.g. Brebner, 2003; Eid \& Diener, 2001; Laros \& Steenkamp, 2005). Emotions developed to effectively solve adaptive problems faced by our hunter-gatherer ancestors (Tooby \& Cosmides, 2008). Hence, emotions are triggered because of something, vary in intensity and tend to lead to - sometimes subtle - behavioural outcomes (Frijda, 1993; Larsen et al., 2009; Rank \& Frese, 2008; Solomon, 2008). Consequently, emotions can be characterised as information-processing functions combining thoughts and behaviour; they derive from the individuals' evaluations of triggering events and thus have a cognitive origin (Soscia, 2013). 
The study of emotions is primarily the study of change and flow over time and across occasions (Lazarus, 1991). To understand how emotion is generated and unfolds the four stages of the process, i.e. anticipation, provocation, unfolding and outcome needs to be examined in detail (Lazarus 1991). This emotion process is what we refer to also as emotion episodes (cf. Holmlund, 2004; Tian et al., in press). Emotions are also defined as an emergent, dynamic process (Scherer, 2009). Dynamic in emotion literature refers to changes for example, in the intensity of emotion over time (e.g. Verduyn et al., 2009). In this study, the focus is not on the emotion process per se, i.e. how emotions emerge or how they change over time. Our study is explorative and focusing inductively on what emotions top managers and key persons experience during the integration stage, what triggers these emotions and what outcomes these emotions migh have.

How individuals come to experience emotions has been discussed in detail within the psychological (e.g. Frijda, 1987; Lazarus, 1993) and sociological literature (e.g. Thoits, 1989). The psychology stream sees all emotional experiences as rooted in a prior interpretation process (termed "appraisal") involving the evaluation and interpretation of situations in which individuals find themselves. It is argued that an individual feels a certain emotion after a given event as a result of this process of appraisal (e.g. Frijda, 1987; Lazarus, 1993). The sociological view argues that emotions are not simply innate psychological phenomena (Thoits, 1989) but result from social structures and are learned and experienced because of social interactions (Thoits, 1989). Positive emotions tend to spread (i.e. fuel more positive emotions in others), whereas negative emotions may lead to a wider variety of emotional expressions in others (Chmiel et al., 2011). Additionally, individuals in their interactions tend to mimic the behaviour of others and to feel the emotions they express (Duclos et al., 1989); they tend to become automatically emotionally attuned with others (Bartel \& Saavedra, 2000). Further, emotions are shaped by an organisation's social 
interactions (Sieben \& Wettergren, 2010). Consequently, within organisations, emotions can be viewed as having two levels; they are the result of an individual's personal appraisal of events but are also influenced by social interactions that individuals engage in.

In line with current work in the organisation studies and M\&A fields, we draw from cognitive appraisal theory from the psychology literature. Within organisational settings, events that can lead to an emotional appraisal have frequently been studied through the lens of affective events theory (AET) (Kiefer, 2002; Sinkovics et al., 2011). Per AET, specific events or situations within the workplace can trigger emotions. These "affective events" are triggered by specific interactions and are impacted by the environment in which they happen such as M\&A processes. The cognitive appraisal and affective event theories view emotions as intermediary between the antecedents (the events) and the outcomes (actions) (cf. Kusstatscher \& Cooper, 2005; Sinkovics et al., 2011). In emotion literature the cause of a cognitive appraisal and emotions has been defined as emotion-eliciting events or situations (Menges \& Kilduff, 2015; Zeelenberg \& Pieters, 2006), precipitating events (Zeelenberg \& Pieters, 2006) and 'antecedent event' (e.g. Sinkovics et al. 2011). However, emotions can be cognitive appraisals of, for instance, individuals and issues, in addition of events, or situations (Lazarus, 1991; Roseman, Spindel, and Jose, 1990). Hence, in this study trigger refers to anything, an event, an action, a mood anything that 'triggers' a cognitive appraisal (emotion).

In sum, emotions are at the core of attitude formation and behaviour in organisations (e.g. Ashkanasy \& Daus, 2002). Despite the episodic nature of emotions, emotions are dynamic (Fredrickson, 2013; Oh \& Farh, 2017). This research addresses two gaps identified by Ashkanasy and Humphrey (2011), namely the need for within-person research and the need to take more account of the context in studies of emotions in organisations. Accordingly, this research focuses on the within-person level, on momentary temporal 
variations in within-person emotion as experienced by individual organisational members, in this case top managers and key persons involved in the M\&A process (Ashkanasy \& Humphrey, 2011). This research also contributes to emotion research by focusing on the dynamic emotional experience (cf. Kiefer, 2012; Oh \& Fahr, 2017). With this research we focus on the basic emotions (cf. Laros \& Steenkamp, 2005), and we build on the analytical framework of the role of emotions in M\&As proposed by Sinkovics et al. (2011; see also Kusstatscher \& Cooper, 2005), which is presented in more detail in the next section.

\subsection{Emotions in mergers and acquisitions}

M\&As have been described as stressful and emotional organisational/life events (e.g. Ager, 2011; Gunkel et al., 2015; Kusstatscher \& Cooper, 2005; Sinkovics et al., 2011) which elicit emotions among large groups of people (Huy, 2012). Emotions may occur in any part or level of the organisations involved, and may be positive or negative about the entire M\&A process or parts of it (Sinkovics et al., 2011). Managers' challenges during the post-M\&A stage include identifying and managing negative emotions and while they themselves might be experiencing various emotions, they must be able to express the right emotions at the right time (cf. Ashkanasy \& Daus, 2002). Their emotions may ultimately impact the performance of their group (cf. Gooty et al., 2010; Kaplan et al., 2014; Sy et al., 2005). Additionally, due to their senior position and potential retention contracts, managers are generally more restricted in terms of acting/reacting to emotional triggers and to their true emotions.

M\&As may trigger a wide variety of emotions. As mentioned earlier, a significant body of literature focuses on negative emotional experiences as an M\&A feature that must be overcome and managed (e.g. Kusstatscher \& Cooper, 2005; Sinkovics et al., 2011). Uncertainty about the future fuelled by rumours about restructuring, job losses and perceived threats to social identity may trigger a range of negative emotions (Kusstatscher \& Cooper, 
2005; Sinkovics et al., 2011). Emotions related to M\&As often result in attitudes and behavioural outcomes such as decreased motivation, job withdrawal, lower job satisfaction and reduced commitment towards the company and even decreased well-being and deteriorating health (Kusstatscher \& Cooper, 2005; Sinkovics et al., 2011). However, managers usually have more information about the M\&A process and may not experience M\&As in the same way as employees do. While they may display a wide array of emotions, the triggers may be different. Accordingly, prior research suggests that employees in higher hierarchical positions show less feelings of insecurity but higher turnover intentions (Gunkel et al., 2015).

To analyse the triggers and consequences of acquired top managers and key persons' emotions in cross-border acquisitions, this study builds and extends on the analytical framework presented by Sinkovics et al. (2011; see also Kusstatscher \& Cooper, 2005). Sinkovics et al. (2011) present a conceptual framework for analysing emotions in M\&As. The framework is based on the AET and suggests that emotions plays an intermediary role in M\&As. Consequently, employees' attitudes and behaviours is resulting from the emotions triggered by the appraisal of various M\&A related event (Sinkovics et al. 2011). We contributed to the work of Sinkovics et al. (2011) in three ways. First, while Sinkovics et al. (2011) focus on employees' emotions, and how these are triggered by subjectively-perceived managerial stimuli, we focus on the emotional experience of top managers and key persons. Second, instead of focusing on emotions identified in M\&A literature, we draw on psychological literature on emotion theories, and analyse more broadly the basic emotions (positive and negative) (Laros \& Steenkamp, 2005). Finally, in order to obtain a deeper understanding of the emotion experience, we do not limit our analysis to M\&A related event/triggers per se, but analyse more inductively (and broadly) what triggers emotions in top managers and key persons during the post-M\&A integration stage. Figure 1 below 
illustrates our analytical framework drawing from cognitive appraisal theory, AET, inspired by Sinkovics et al. (2011).

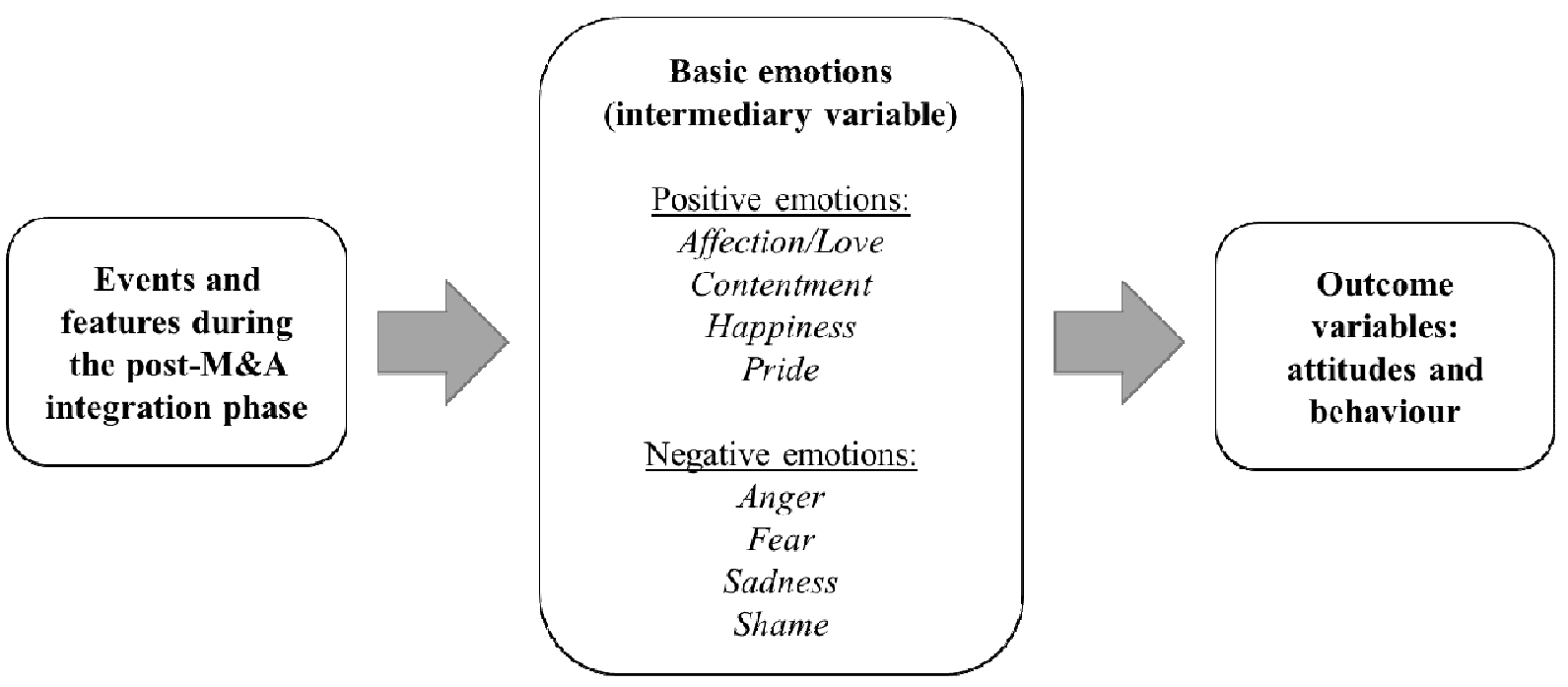

Figure 1 An emotion framework to analyse emotions in M\&A inspired by Sinkovics et al. (2011) and Laros and Steenkamp (2005)

In sum, M\&As trigger a range of emotions, positive and negative, and prior studies have identified several triggers and outcomes of emotions during M\&As (e.g. Kusstatscher \& Cooper, 2005; Kusstatscher, 2006; Sinkovics et al., 2011). We argue that top managers and key persons are in a critical position in managing employees' emotions during the M\&A process (e.g. Gunkel et al., 2015; Kusstatscher \& Cooper, 2005; Sinkovics et al., 2011), and understanding their emotional experience during the post-M\&A integration stage is critical for successfully manage the post-M\&A integration. In the following empirical section, we explore the emotional experience of top managers and key persons in the context of a single case study: an Indian-Finnish acquisition.

\section{Research methodology}

3.1 Research strategy: A longitudinal single case study 
This research applied a longitudinal, single case study approach (cf. Pettigrew, 1990; Van de Ven, 1992). As the main aim of the study is to analyse the emotional experience of top managers and key persons during the post-acquisition stage, this approach was seen as the most suitable method, enabling a rich and contextualised description of the phenomenon under scrutiny (cf. Eisenhardt, 1989; Stake, 1995; Yin, 2014). Past studies show that individuals may experience different - even opposite - emotions at the same time (Carrera \& Oceja, 2007) and that their emotions change both in existence (Filipowicz et al., 2011) and in intensity (Carrera \& Oceja, 2007). Hence, to capture a comprehensive understanding of emotions, Larsen et al. (2009) encouraged the temporal dimension to be included in emotion research, and thus we adopted a longitudinal approach to analyse emotions during the postM\&A integration stage. The post-M\&A integration stage offers a temporal context, where we study emotional states as non-temporally contiguous episodes (cf. Holmlund, 2004; Tian et al., in press). Our study is essentially a qualitative and explorative research, where our focus lies on the emotional experience of top managers and key persons during the post-M\&A integration stage, i.e. what emotions they experience, what triggers their emotions and what are the outcomes (cf. Sinkovics et al., 2011). Emotional experience refers to the individual's (self) impressions of emotion episodes (Lazarus, 1991). It has been argued that a phenomenological approach to emotions provides important insights into the meaningfulness of the human experience (Elpidorou \& Freeman, 2014).

Our case study approach employing a "typical" case with an illustrative role (was used to illustrate key persons' emotions in the M\&A context (cf. Siggelkow, 2007), to extend and build on the existing conceptual framework presented by Sinkovics et al. (2011) and to illustrate its applicability to analysing acquired key persons' emotions. Our case is "typical" as it represents a cross-border acquisition in the IT field, which fulfils the definition given in the literature (e.g. Jagersma, 2005). A suitable case needs to meet several requirements. The 
most important criteria, beyond the obvious requirement regarding the international nature of the acquisition, is that the case is somewhat emotional. By this we do not mean an extreme case that could easily become a "self-fulfilling prophesy". Instead, we were looking for a typical cross-border acquisition where the owners would be selling their company to a foreign owner. The deal had to be a majority acquisition so that the acquirer could take control of the target company; relatively recent to avoid retrospective bias during the interviews and allow real-time data collection. The opportunity to study an Indian-Finnish acquisition presented itself and the case proved to be suitable (and interesting). Firstly, access to data for a long enough period was crucial. The case company agreed to sign a contract permitting research and data collection for two years from deal closure and this was tied to the fact that some top managers and key persons had to sign a two-year contract agreeing to remain in the organisation and would therefore also be available for the research. Secondly, the Finnish company was relatively small, had a family atmosphere and was still run by the founders of the company, which made the selling of the firm very emotional. As such, it represents a typical small or medium-sized company being acquired. It was likely that this case study would reveal a significant amount about key persons' emotions during the postacquisition integration stage. Thirdly, being a cross-border acquisition, this case represents a typical situation in IB where the parent company must manage emotions in a subsidiary located geographically in a different country if not on a different continent, as in this case. Thus, this case can be regarded as a typical and illustrative case in the IB and M\&A field (e.g. Siggelkow, 2007; Stake, 1995; Yin, 2014). This research focused on the acquired Finnish firm, as the underlying assumption was that the acquisition would be more emotional in the target firm where the owners had to sell their company.

\subsection{Data collection and analysis}


The empirical research is based on qualitative interview data. The interviews were semistructured with mostly open-ended questions (see Table A.10 in Appendix). A panel of thirteen key persons comprising top and middle managers, key account managers and two lead engineers. Some were former founders and minority shareholders of "Alpha". (see Table A.11 in Appendix) The participants were interviewed longitudinally during the post-M\&A integration stage in three rounds during 2007 and 2008, resulting in 39 interviews. The interviews took place at approximately six-month intervals to capture the emotions following the progression of the integration stage. They were held at the various organisation sites of the acquired Alpha in Finland. The interviews were conducted in Finnish, the mother tongue of both the interviewer and the interviewees (cf. Welch et al., 2002). The interviews were tape-recorded with the consent of each interviewee. The duration of the interviews varied from 30 minutes to 1 hour and 20 minutes. In addition to the interview data, the primary data consisted of photos of the various offices and locations, and observations. Moreover, a case diary was kept, containing observations from the interviews at different locations (cf. Kvale, 1996).

The data analysis was conducted in several steps. First, to enable content analysis, the interviews were transcribed by a professional agency and then analysed using Nvivo 10 software. Despite the qualitative nature of the study we did not adopt a purely inductive approach (cf. Gioia et al., 2013), as our observations and analysis were partially guided by initial hunches and frames of reference (see Siggelkow, 2007). Consequently, our coding scheme initially relied heavily on our research questions and on the frames of reference presented in our literature review (cf. Kusstatscher \& Cooper, 2005; Sinkovics et al., 2011). Our analysis and coding was an iterative process between the data and the literature.

In the first analysis round, we relied on a priori codes, and had only two main nodes ("positive emotions" and "negative emotions"). Firstly, we searched for "explicit 
expressions" of emotions, mostly for emotive verbs, for example "I'm annoyed" (irritation; subcategory of anger). Secondly, we searched for "implicit expressions" (see e.g. Balahur, Hermida, \& Montoyo, 2012). This required more interpretation, for example "There were many uncertainties and we were a bit unsure about our future prospects here" (worried; subcategory of fear). Accordingly, emotions referring to either theme were coded under these main nodes without any further analysis at this stage. The coding was intentionally kept rough during the first round. In the second round, the coded nodes were analysed in more depth. Distinct emotions found in the data were coded deductively utilising the typology of basic emotions that has been successfully employed in earlier business studies (Brebner, 2003; Eid \& Diener, 2001; Laros \& Steenkamp, 2005) (see Table 1 below). This method enabled us to go deeper and deeper into our data during each round. Once the coding process was complete, we built the analysis into a data structure. We carefully analysed the triggers for the emotions and identified the consequences.

Table 1 Operationalisation of basic emotions and their sub-emotions (based on Laros \& Steenkamp, 2005)

\begin{tabular}{|l|l|l|l|}
\hline \multicolumn{2}{|c|}{ Positive emotions } & \multicolumn{2}{c|}{ Negative emotions } \\
\hline Basic emotions & Sub-emotions & Basic emotions & Sub-emotions \\
\hline Affection & $\begin{array}{l}\text { Sexy, romantic, passionate, loving, } \\
\text { sentimental, warm-hearted }\end{array}$ & Anger & $\begin{array}{l}\text { Angry, frustrated, irritated, } \\
\text { unfulfilled, discontented, envious, } \\
\text { jealous }\end{array}$ \\
\hline Contentment & Contented, fulfilled, peaceful. & Fear & $\begin{array}{l}\text { Scared, afraid, panicky, nervous, } \\
\text { worried, tense. }\end{array}$ \\
\hline Pride & $\begin{array}{l}\text { Optimistic, encouraged, hopeful, } \\
\text { happy, pleased, joyful, relieved, } \\
\text { thrilled, enthusiastic }\end{array}$ & Sadness & $\begin{array}{l}\text { Depressed, sad, miserable, } \\
\text { helpless, nostalgia, guilty }\end{array}$ \\
\hline
\end{tabular}


Several measures were taken to minimise bias and increase trustworthiness in this research. To enhance the trustworthiness of the qualitative analysis process, we used Nvivo software and followed recommendations regarding qualitative analysis of primary interview data (Sinkovics, Penz, \& Ghauri, 2008; Sinkovics \& Alfoldi, 2012). We assessed the trustworthiness of our qualitative research in terms credibility, dependability, transferability, and confirmability (Lincoln \& Cuba, 1985). In terms of credibility, we used existing literature to frame the research problem appropriately. The longitudinal research approach increased credibility by building trust with the interviewees over the three interview rounds. Developing a deep rapport with the interviewees was necessary to gain honest and accurate responses and the longitudinal research approach increased trustworthiness by building trust during the different interview rounds (Daniels \& Cannice, 2004). Emotions are extremely hard to remember retrospectively (Robinson \& Clore, 2002), hence the interview data was collected in real time as the integration process progressed. Transferability has been enhanced by accurately describing in detailed and honest manner the entire research process. A detailed audit trail, for example list of interviewees and interview guide (see Table A10 and A11 in Appendix) enhances confirmability. All these together increases dependability. (Lincoln \& Cuba, 1985). As this study focuses on the emotions of top managers and key persons during the post-acquisition stage, the results are based on interviewees' subjective perceptions of, their feelings about and their experiences regarding the acquisition (Lander \& Kooning, 2013).

\section{Findings}

\subsection{Background of the case}

To protect company anonymity, the names of the two organisations are not revealed. The acquired company was a medium-sized Finnish high-tech company (Alpha Group) operating 
as a sub-contractor in the field of telecommunications and employing around 300 workers. It was acquired in 2006 by an Indian company (Gamma Group) who had 3000 employees. The nature of the deal can be defined as friendly. Both companies were looking for a partner to grow and become more international. The acquisition type could be defined as a concentric acquisition as both companies operated in the same field, although in different areas (Cartwright \& Cooper, 1992): Gamma Group in software engineering and Alpha Group in both software and hardware engineering.

This acquisition had multiple motives. Alpha's main motives were to internationalise and grow. The market was extremely competitive and organic growth in the European market was becoming ever more difficult. Moreover, Alpha was extremely dependent on one key account, which alone represented around $90 \%$ of sales. Alpha's key account put pressure on its suppliers, including Alpha, by requiring growth, a global footprint and the reduction of costs as well as proximity centres particularly in India and China. While Alpha needed to meet these demands, it had also become crucial to expand their customer base. The acquirer Gamma could offer both an international scope and wider customer base. Gamma was also chosen for its reasonable size compared to Alpha and its similar values. Gamma's main acquisition motives were to acquire Alpha's key customer, obtain a foothold in Europe and acquire new competences in both hardware and software engineering.

The acquisition took place during the peak holiday season in Finland. It was announced to employees via email on the same day but as many employees were on holiday and unreachable, some read the news from their local paper or heard it on the radio. Employee information meetings were arranged a month or so after the M\&A announcement and the parent company did its best to reassure the employees that no major changes would take place and that it wanted Alpha Group to carry on as usual. The former owners of Alpha had expressed their wish for a slow and gentle integration and the parent company Gamma did its 
best to respect this wish as well as the local Finnish culture in Alpha Group. Alpha had performed well until then and the Indian parent company wanted to secure a successful business with Alpha. The company name "Alpha Group" was changed to Gamma Europe in spring 2007, nine months' post-deal. A positive atmosphere and the visibility of the Indian parent organisation were enhanced by various employee events, all of which contributed to cultural integration. While there was only minor restructuring in Gamma Europe, the parent company experienced several organisational changes one after another a little over a year after the acquisition. In autumn 2007, Alpha Group's CEO resigned and a new CEO from within the former Alpha Group was appointed. The visibility of the Indian parent organisation was enhanced through visits by Indian top managers to quarterly meetings.

The integration process progressed slowly and focused on operational issues such as HR, IT and finance. The main challenge was a lack of understanding as to why things were being done as they were. Despite the relatively high cultural awareness of Gamma Europe, dealing with the actual cultural differences was challenging. Other major challenges were related to communication in terms of language difficulties and the need to use English, as well as management and leadership. Moreover, the decision-making style was seen as hierarchical and bureaucratic in India and in general was felt to take too long.

\subsection{Emotions expressed during the post-acquisition stage}

Contrary to the dominant literature emphasising negative attitudes and emotions during M\&As (cf. Kusstatscher \& Cooper, 2005; Sinkovics et al., 2011), our main findings suggest that key persons experience a wide array of both positive and negative emotions during M\&As (cf. Kiefer, 2002; Kusstatscher \& Cooper, 2005). Based on the data, the incidences of positive and negative emotions experienced were nearly the same: we coded 81 positive and 83 negative emotion types. Table 2 below also demonstrates how positive emotions were 
slightly more dominant than negative emotions in the first and second data-collection rounds (spring 2007 and autumn 2007), while in round three (summer 2008), negative emotions dominated.

Table 2 The different types of emotions and their distribution during the postacquisition integration stage

\begin{tabular}{|l|c|c|c|c|}
\hline Emotion & Time I & Time III & Time III & TOTAL \\
\hline POSITIVE & $\mathbf{2 4}$ & $\mathbf{4 4}$ & $\mathbf{1 4}$ & $\mathbf{8 1}$ \\
\hline Contentment & 11 & 21 & 9 & 41 \\
\hline Happiness & 9 & 22 & 5 & 35 \\
\hline Love & 1 & - & - & 1 \\
\hline Pride & 3 & 1 & - & 4 \\
\hline NEGATIVE & $\mathbf{2 0}$ & $\mathbf{3 1}$ & $\mathbf{3 2}$ & $\mathbf{8 3}$ \\
\hline Anger & 2 & 22 & 29 & 53 \\
\hline Fear & 10 & 7 & 3 & 20 \\
\hline Sadness & 8 & 2 & - & 10 \\
\hline Shame & - & - & - & 0 \\
\hline
\end{tabular}

Table 2 above demonstrates how interviewees experienced all types of emotions except for shame. While the range of emotions was wider during the first round of interviews in spring 2007 (six months' post-deal), the level of emotionality was higher during the second data-collection round in autumn 2007 and anger was expressed particularly strongly nearly two years' post-acquisition. Interestingly, emotions of happiness and contentment were the strongest over a year post-deal, while at the same time anger was equally strong. Nearly two years after the deal, negative emotions became more dominant. Fears had reduced, but anger had reached a record level by time III. Figure 2 summarises the proportion of experienced negative and positive emotions. Due to the short-term nature of emotions, and the lack of evidence regarding how emotions fluctuated in between the data-collection points, the data is described as bar charts. 


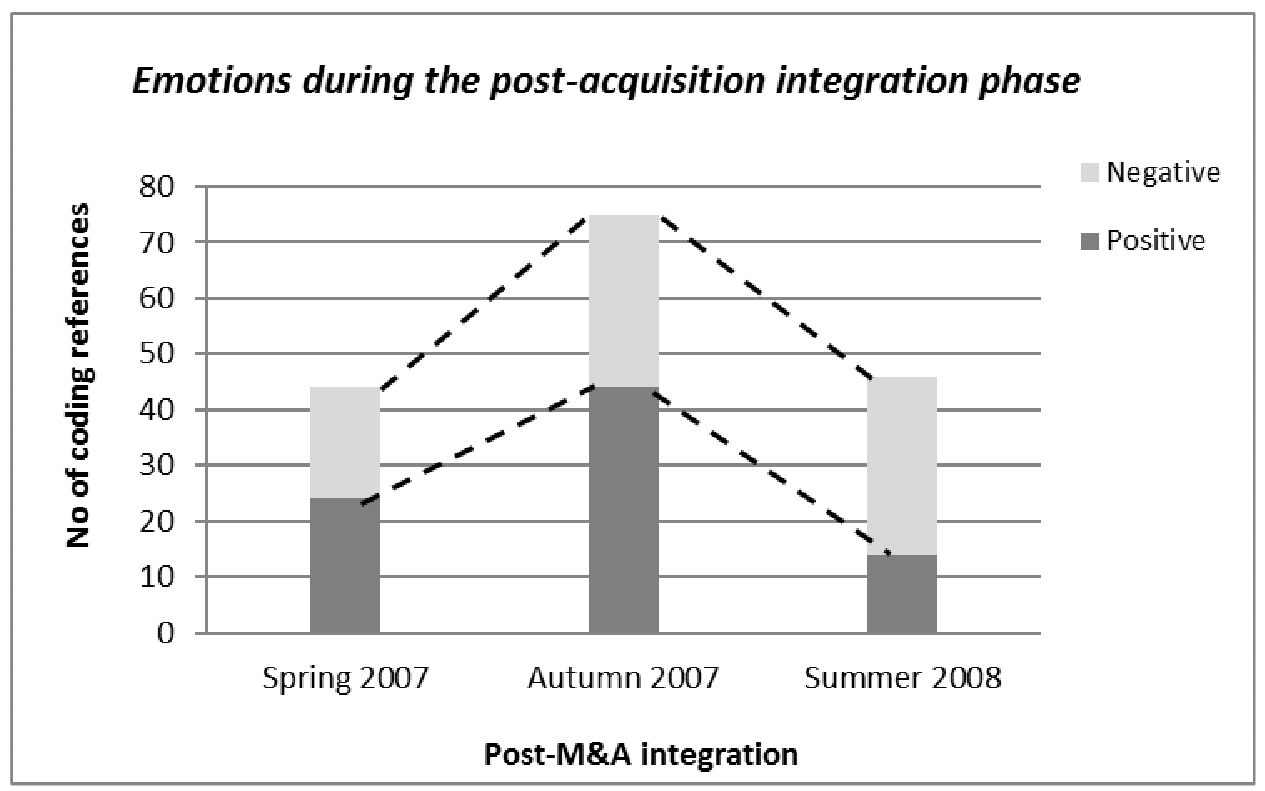

Figure 2 The distribution of negative and positive emotions during the post-acquisition integration stage

In sum, the findings clearly illustrate the wide variety of emotions experienced during the post-acquisition integration stage. The interviews revealed that early in the process, positive emotions were related to contentment and happiness with the deal (i.e. the price and the chance to secure the company's future) and negative emotions (fear for the future, uncertainty and sadness at selling the company) also prevailed. Such strong emotions just one year post-acquisition can be explained by both parties knowing each other better and the integration process being more advanced, thus reflecting the acculturation between the two organisations - the process of contact, conflict and adaptation (cf. Cartwright \& Cooper, 1993). The findings reveal how emotions can run high even two years' post-deal. In the next section, we discuss in more detail what triggered the different emotions.

\subsection{Emotions and triggers during the post-acquisition integration stage}


Prior research suggests that employees' emotions are triggered by how they experience and appraise M\&A-related features and events in relation to their work and job (cf. Kusstatscher \& Cooper, 2005; Sinkovics et al., 2011). However, based on our findings emotion triggers can be divided into individual-level and company-level factors. Individual triggers refer to individual specific events/situations such as selling one's ownership, new career perspectives, loss of control or loss of decision-making power. Company-level triggers refer to companyspecific events/situations such as future prospects, internationalisation opportunities, unfulfilled expectations or cultural differences. Next we analyse emotions and triggers at each data collection time.

\subsubsection{Emotions at time I- the honeymoon stage}

Findings six to eight months following the closing of deal reveal a vast variety of both positive and negative emotions. All four positive basic emotions emerged from the data, i.e. contentment, happiness, affection (love) and pride (Laros \& Steenkamp, 2005). Contentment and happiness were the most cited emotions. These emotions were triggered by the acquisition, i.e. selling the company, the selling price, the acquirer ("the right company") and the future internationalisation and growth potential of the company (see Table 3 below). Interviewees experienced happiness, a sense of relief and contentment about selling the company. The deal went better than they expected and the acquirer was felt to be the right company for Alpha. There was an emotion of pride related to what the acquired company stood for and had achieved and love and passion towards work. The acquisition enabled Alpha to stay on a growth path and internationalise. 
Table 3 Positive emotions and triggers related to the acquisition and the first 6 months

\begin{tabular}{|c|c|c|c|c|}
\hline \multicolumn{5}{|c|}{ Positive emotions Time I } \\
\hline Trigger & Source & $\begin{array}{l}\text { Examples of } \\
\text { emotions }\end{array}$ & Intervie w quotes & Interviewee \\
\hline $\begin{array}{l}\text { Selling the } \\
\text { ownership }\end{array}$ & Individual & $\begin{array}{l}\text { Happiness - } \\
\text { relieved, happy }\end{array}$ & $\begin{array}{l}\text { "..well in a way now I don't have to think } \\
\text { about ownership or stress about such things } \\
\text { at all, I can now enjoy, take it easier } \\
\text { regarding how the firm is doing.." }\end{array}$ & $\begin{array}{l}\text { Lead Engineer } \\
1, \text { round } 1 \text { spring } \\
2007\end{array}$ \\
\hline Selling price & Individual & $\begin{array}{l}\text { Contentment - } \\
\text { contented with } \\
\text { the sale }\end{array}$ & $\begin{array}{l}\text { "..the deal went better than I could have } \\
\text { imagined, the entire exit.. When we sometimes } \\
\text { thought with our small group what are our } \\
\text { opportunities and how much we could make } \\
\text { from this, in that respect our expecations have } \\
\text { been surpassed.[..] I am very pleased with the } \\
\text { entire arrangement." }\end{array}$ & $\begin{array}{l}\text { Director } 3, \\
\text { round } 1 \text { spring } \\
2007\end{array}$ \\
\hline Current job & Individual & $\begin{array}{l}\text { Love - passion } \\
\text { about work }\end{array}$ & $\begin{array}{l}\text { "..I have a weird internal need to do exactly } \\
\text { what I am doing as a living, for example I was } \\
\text { a year ago in a position where I could do } \\
\text { software engineering. I was writing reports } \\
\text { here at work, so I had in the evening at home } \\
\text { do software engineering.. It is just a passion } \\
\text { for this job.." }\end{array}$ & $\begin{array}{l}\text { Lead Engineer } \\
2 \text {, round } 1 \text { spring } \\
2007\end{array}$ \\
\hline $\begin{array}{l}\text { Organisational } \\
\text { identity, } \\
\text { acquired } \\
\text { company } \\
\end{array}$ & Corporate & Pride & $\begin{array}{l}\text { "..we are one of the best in terms of } \\
\text { knowledge and what we do, our customer } \\
\text { values us.." }\end{array}$ & $\begin{array}{l}\text { Account } \\
\text { Manager } 1 \\
\text { round } 1 \text { spring } \\
2007\end{array}$ \\
\hline $\begin{array}{l}\text { Acquire } r \text { from } \\
\text { India }\end{array}$ & Corporate & $\begin{array}{l}\text { Happiness - } \\
\text { enthusiastic }\end{array}$ & $\begin{array}{l}\text { ".. it felt like the right company from the very } \\
\text { beginning, and when talking with him and } \\
\text { studied more his speeches and organizational } \\
\text { values, and he cites Gandhi in many places. } \\
\text { [.. ] and now just out of interest I have started } \\
\text { to read and studied them, and all the time, } \\
\text { more and more he feels like an intelligent man } \\
\text { who has created a good ideology and culture } \\
\text { to Gamma India.. if only we could get that }\end{array}$ & $\begin{array}{l}\text { Director } 2, \\
\text { round } 1 \text { spring } \\
2007\end{array}$ \\
\hline $\begin{array}{l}\text { Inte rnationalis at } \\
\text { ion possibilities/ } \\
\text { growth potential }\end{array}$ & Corporate & $\begin{array}{l}\text { Happiness - } \\
\text { optimistic }\end{array}$ & $\begin{array}{l}\text { "..it }(M \& A) \text { represents new opportunities, in } \\
\text { terms of internationalization and growth, and } \\
\text { gives an extra boost to the company.." }\end{array}$ & $\begin{array}{l}\text { Director } 4, \\
\text { round } 1 \text { spring } \\
2007\end{array}$ \\
\hline
\end{tabular}

Three negative basic emotions emerged from the data: fear, sadness and anger. Fear and sadness were the dominant emotions at time I. While selling the company triggered happiness and contentment in some interviewees, it triggered sadness and nostalgia related to the loss of ownership, selling one's life work and loss of independence in others. Uncertainty about the 
future, news about outsourcing to low-cost locations, and lack of information regarding the acquisition aroused emotions of fear and worry. While some welcomed the name change from Alpha Group to Gamma Europe, a few expressed anger towards this change. These emotions are typical in the post-acquisition integration stage and are well documented in prior M\&A research (eg. Kusstatscher \& Cooper, 2005). (see Table 4 below) 
Table 4 Negative emotions and triggers related to the acquisition and the first 6 months

\begin{tabular}{|c|c|c|c|c|}
\hline \multicolumn{5}{|c|}{ Negative emotions Time I } \\
\hline Trigger & Source & $\begin{array}{l}\text { Examples of } \\
\text { emotions }\end{array}$ & Intervie w quotes & Interviewee \\
\hline $\begin{array}{l}\text { Selling the } \\
\text { owne rs hip }\end{array}$ & Individual & $\begin{array}{l}\text { Sadness - } \\
\text { nostalgia }\end{array}$ & $\begin{array}{l}\text { "..when we closed the deal it felt like I had } \\
\text { sold my soul, and now I am working for } \\
\text { someone else, and how much will they now } \\
\text { tell me what to do from India.." }\end{array}$ & $\begin{array}{l}\text { Director } 2 \text {, round } 1 \\
\text { spring } 2007\end{array}$ \\
\hline $\begin{array}{l}\text { Loss of } \\
\text { independence }\end{array}$ & Individual & $\begin{array}{l}\text { Sadness - } \\
\text { nostalgia }\end{array}$ & $\begin{array}{l}\text { ".. In a way we lost the last reins, in that } \\
\text { sense if was a major step.." }\end{array}$ & $\begin{array}{l}\text { Lead Engineer 2, } \\
\text { round } 1 \text { spring } \\
2007\end{array}$ \\
\hline $\begin{array}{l}\text { Selling own's } \\
\text { life work }\end{array}$ & Individual & $\begin{array}{l}\text { Sadness - } \\
\text { nostalgia }\end{array}$ & $\begin{array}{l}\text { "..I was making those decicions (to sell) } \\
\text { and when it happened, it wasn't anymore } \\
\text { the biggest issue, personally I had to make } \\
\text { the key decisions two or one year in } \\
\text { advance.. To adjust to the idea that I am } \\
\text { sort of selling my life's work.." }\end{array}$ & $\begin{array}{l}\text { Director } 2 \text {, round } 1 \\
\text { spring } 2007\end{array}$ \\
\hline $\begin{array}{l}\text { Uncertainty } \\
\text { about the } \\
\text { location of } \\
\text { business } \\
\text { functions in } \\
\text { the future }\end{array}$ & Individual & Fear - worried & $\begin{array}{l}\text { ".. We were uncertain about our work here. } \\
\text { And as this (M\&A) coinsided with our main } \\
\text { customer, who without us knowning, had } \\
\text { transferred some functions to Bangalore, } \\
\text { where our current owner is located .....] } \\
\text { well we started to think how will it be in the } \\
\text { future, will all our jobs go there (India).." }\end{array}$ & $\begin{array}{l}\text { Engineer Manager } \\
1 \text {, round } 1 \text { spring } \\
2007\end{array}$ \\
\hline $\begin{array}{l}\text { News about } \\
\text { outs ourcing in } \\
\text { media }\end{array}$ & Individual & Fear - worried & $\begin{array}{l}\text { "..there is a big fear, that can easily come } \\
\text { among employees, as there are constantly } \\
\text { news about how jobs go to low-cost } \\
\text { economies and what will happen with our } \\
\text { jobs here, they can suddenly close down } \\
\text { everything here.." }\end{array}$ & $\begin{array}{l}\text { Engineer Manager } \\
1 \text {, round } 1 \text { spring } \\
2007\end{array}$ \\
\hline $\begin{array}{l}\text { Uncertainty } \\
\text { about the } \\
\text { business } \\
\text { success in } \\
\text { future }\end{array}$ & Corporate & Fear - worried & $\begin{array}{l}\text { "..I am always worried about the duccess.. } \\
\text { When there is a lot of work, I have faith } \\
\text { that the business will succeed and continue, } \\
\text { but the last two or three years growth has } \\
\text { stagnated..the worry about the future grew } \\
\text { all the time..." }\end{array}$ & $\begin{array}{l}\text { Director } 2 \text {, round } 1 \\
\text { spring } 2007\end{array}$ \\
\hline $\begin{array}{l}\text { Lack of } \\
\text { information }\end{array}$ & Corporate & Fear - worried & $\begin{array}{l}\text { "..in Finland it was summer holidays when } \\
\text { the deal was closed, which was the worst } \\
\text { case as it launched an enormous wave as } \\
\text { people started to call each other regarding } \\
\text { what does this mean, and what will happen, } \\
\text { and will they lose their jobs.. The staff } \\
\text { information was held afterwards..something } \\
\text { that should have been organised } \\
\text { differently, the staff information meetings } \\
\text { should have been held right after.." }\end{array}$ & $\begin{array}{l}\text { Engineer Manager } \\
1 \text {, round } 1 \text { spring } \\
2007\end{array}$ \\
\hline
\end{tabular}


In sum, at time I emotions ranged from happiness, contentment, love and pride to fear, sadness and anger. Interestingly, based on our findings one trigger could evoke both negative and positive emotions. For example, selling the company aroused happiness about the deal and how well it went but it also aroused emotions of sadness and nostalgia related to the loss of one's life work. Emotions emerging from the data at time I reflect the initial stage of the post-acquisition integration stage, hence we call this stage the 'honeymoon stage'. Only top managers and key persons had been in contact with the acquiring firm and apart from the integration and changes in Finance, integration had been moderate. Alpha Group's name was about to be changed into Gamma Europe, a change that many welcomed in order to clarify the new identity not only within the organisation but also towards external stakeholders.

\subsubsection{Emotions at time II - reality stage}

At time II, fourteen to sixteen months after the deal, the dominant emotions are happiness, contentment, anger and fear. These emotions and triggers again reflect well the stage Gamma Europe is with the integration process. The company name has been changed and Gamma Group in India is undergoing a first major restructuring since the acquisition. However, there was a sense that the organisational changes did not concern Gamma Europe much. Employees and managers in Gamma Europe had more contact with their Indian parent company through new Indian line managers and a dozen Indian Engineers came to Finland through an Engineer Exchange Program. Individual triggers for positive emotions such as happiness are related to diminished responsibility following the deal and new career prospects in a larger organisation. Interestingly the proportion of company-level triggers related to positive emotions is much higher than individual triggers. Company-level triggers are related to promising future prospects of the company, good financial result, increased 
demand and encouraging feedback from customers as well as to the new identity following the name change and recruiting talent becoming easier. (See Table 5 below.) 
Table 5 Positive emotions and triggers at Time II

\begin{tabular}{|c|c|c|c|c|}
\hline \multicolumn{5}{|c|}{ Positive emotions Time II } \\
\hline Trigger & Source & \begin{tabular}{|l} 
Examples of \\
emotions
\end{tabular} & Intervie w quotes & Intervie wee \\
\hline $\begin{array}{l}\text { Less } \\
\text { responsibility }\end{array}$ & Individual & $\begin{array}{l}\text { Happiness - } \\
\text { relieved }\end{array}$ & $\begin{array}{l}\text { "..the responsibilities have diminished, } \\
\text { particularly in this new position where I don't } \\
\text { have any subordinates and I am not } \\
\text { responsible of anything, it has made it easier, } \\
\text { I can freely focus on thinking about what are } \\
\text { we going to do.." }\end{array}$ & $\begin{array}{l}\text { Director } 3 \text {, round } \\
2 \text { autumn } 2007\end{array}$ \\
\hline $\begin{array}{l}\text { Career } \\
\text { prospects in a } \\
\text { bigger } \\
\text { organis ation } \\
\end{array}$ & Individual & $\begin{array}{l}\text { Happiness - } \\
\text { hopeful }\end{array}$ & $\begin{array}{l}\text { "..Gamma India is still a relatively small } \\
\text { organisation, that it has growth potential, and } \\
\text { therefore offers career opportunities.." }\end{array}$ & $\begin{array}{l}\text { Account } \\
\text { Manager 2, round } \\
2 \text { autumn } 2007\end{array}$ \\
\hline $\begin{array}{l}\text { Changes in job } \\
\text { content }\end{array}$ & Individual & Contentment & $\begin{array}{l}\text { "I feel positive, my job description is more } \\
\text { thinking and less action, so it allows me to } \\
\text { envision a bit further.." }\end{array}$ & $\begin{array}{l}\text { Director } 3 \text {, round } \\
2 \text { autumn } 2007\end{array}$ \\
\hline $\begin{array}{l}\text { Future } \\
\text { prospects }\end{array}$ & Corporate & $\begin{array}{l}\text { Happiness - } \\
\text { optimistic }\end{array}$ & $\begin{array}{l}\text { "..we have very good chances to manage, } \\
\text { even in the current position, .. even just within } \\
\text { X (main customer) there is still great growth } \\
\text { potential..and also regarding customers } \\
\text { internationally, we probably still have a lot of } \\
\text { work.." }\end{array}$ & $\begin{array}{l}\text { Lead Engineer } 1, \\
\text { round } 2 \text { autumn } \\
2007\end{array}$ \\
\hline $\begin{array}{l}\text { Good financial } \\
\text { results achieved }\end{array}$ & Corporate & $\begin{array}{l}\text { Happiness - } \\
\text { optimistic }\end{array}$ & $\begin{array}{l}\text { "..since a long time our profit exceeded the } \\
\text { budget in the last quartal... I see our future } \\
\text { pretty good as long as we get things } \\
\text { organised and the organisation.. sales etc. to } \\
\text { succeed.." }\end{array}$ & $\begin{array}{l}\text { Engineer } \\
\text { Manager 2, round } \\
2 \text { autumn } 2007\end{array}$ \\
\hline $\begin{array}{l}\text { Easier to recruit } \\
\text { talents }\end{array}$ & Corporate & $\begin{array}{l}\text { Happiness - } \\
\text { relieved }\end{array}$ & $\begin{array}{l}\text { "Recruiting is constantly a challenge, but it } \\
\text { has become evident that it is easier.. People } \\
\text { find it easier, for example a senior staff from } \\
\text { firm X to come and work for us, because we } \\
\text { have grown all the time and we are a pretty } \\
\text { solvent firm, so there are no more fears about } \\
\text { jumping into a small firm which can go under } \\
\text { anytime.." }\end{array}$ & $\begin{array}{l}\text { Lead Engineer 1, } \\
\text { round } 2 \text { autumn } \\
2007\end{array}$ \\
\hline $\begin{array}{l}\text { New company } \\
\text { name }\end{array}$ & Corporate & Contentment & $\begin{array}{l}\text { "..we had the company name changed this } \\
\text { spring, which was good. It was really quite } \\
\text { hard in our job, the job I do, to represent two } \\
\text { brands.. It was very hard. [..] we from the } \\
\text { sales department were strongly advocating for } \\
\text { it, that as we now make changes lets change } \\
\text { the name too.." }\end{array}$ & $\begin{array}{l}\text { Account } \\
\text { Manager 3, round } \\
2 \text { autumn } 2007\end{array}$ \\
\hline $\begin{array}{l}\text { Encouraging } \\
\text { feedback from } \\
\text { customers }\end{array}$ & Corporate & $\begin{array}{l}\text { Happiness - } \\
\text { optimistic }\end{array}$ & $\begin{array}{l}\text { "..there are many good things to come and } \\
\text { also our customers seems to understand that it } \\
\text { is good to have operations also in a more } \\
\text { expensive location, that there are clear } \\
\text { benefits and not everything needs to go to low } \\
\text { cost.." }\end{array}$ & $\begin{array}{l}\text { Director } 3 \text {, round } \\
2 \text { autumn } 2007\end{array}$ \\
\hline $\begin{array}{l}\text { Increased } \\
\text { demand }\end{array}$ & Corporate & $\begin{array}{l}\text { Happiness - } \\
\text { optimistic }\end{array}$ & $\begin{array}{l}\text { "I think our future looks good, our demand } \\
\text { has increased all the time.." }\end{array}$ & $\begin{array}{l}\text { Director } 5 \text {, round } \\
2 \text { autumn } 2007\end{array}$ \\
\hline
\end{tabular}


The findings reveal a clear change in negative emotions at time II. The dominant basic negative emotion was anger. Interestingly, a large proportion of negative emotions were triggered by company-level events. Indian business culture, the M\&A failing to deliver expected outcomes, cultural differences and the slow speed of integration triggered anger and discontentment. Some were irritated by the change of company name; email addresses remained the same causing confusion between the former and new name. There were also fears and worries regarding the capability to exploit the benefits of the acquisition. (See Table 6.) 
Table 6 Negative emotions and triggers at Time II

\begin{tabular}{|c|c|c|c|c|}
\hline \multicolumn{5}{|c|}{ Negative emotions Time II } \\
\hline Trigger & Source & $\begin{array}{l}\text { Examples of } \\
\text { emotions }\end{array}$ & Intervie w quotes & Interviewee \\
\hline $\begin{array}{l}\text { Loss of } \\
\text { decision- } \\
\text { making power }\end{array}$ & Individual & $\begin{array}{l}\text { Anger - } \\
\text { unfulfilled, } \\
\text { discontent }\end{array}$ & $\begin{array}{l}\text { "..my job could be more meaningful in a } \\
\text { smaller organisation, which is a bit twofold, } \\
\text { because on one hand this is exactly what } \\
\text { we wanted... to grow and sell the firm...but } \\
\text { now there is a feeling, well we achieved } \\
\text { that, we did it. And it doesn't feel fulfilling } \\
\text { to continue in this position.." }\end{array}$ & $\begin{array}{l}\text { Lead Engineer } 1, \\
\text { round } 2 \text { autumn } \\
2007\end{array}$ \\
\hline $\begin{array}{l}\text { Acquire r from } \\
\text { India }\end{array}$ & Corporate & $\begin{array}{l}\text { Anger - } \\
\text { discontent }\end{array}$ & $\begin{array}{l}\text { "..it has been a great shock that the } \\
\text { company was acquired by Indians, and that } \\
\text { we are not involved accordingly. These } \\
\text { have come up in the review discussions with } \\
\text { the employees, but I haven't perceived it as } \\
\text { a problem" }\end{array}$ & $\begin{array}{l}\text { Engineer Manager } \\
1, \text { round } 2 \text { autumn } \\
2007\end{array}$ \\
\hline $\begin{array}{l}\text { Failing to } \\
\text { exploit the } \\
\text { be nefits of the } \\
\text { acquisition }\end{array}$ & Corporate & Fear - worried & $\begin{array}{l}\text { ".. Are we able to exploit the resources that } \\
\text { we have elsewhere in the world, and are we } \\
\text { able to boost the growth.. I am starting to } \\
\text { lose faith.." }\end{array}$ & $\begin{array}{l}\text { Account Manager } \\
1, \text { round } 2 \text { autumn } \\
2007\end{array}$ \\
\hline $\begin{array}{l}\text { Unfulfilled } \\
\text { expectations }\end{array}$ & Corporate & $\begin{array}{l}\text { Anger - } \\
\text { discontent }\end{array}$ & $\begin{array}{l}\text { "...it (the M\&A) hasn't delivered the results } \\
\text { we expected and which we set when the } \\
\text { acquisition took place" }\end{array}$ & $\begin{array}{l}\text { Engineer Manager } \\
2 \text {, round } 2 \text { autumn } \\
2007\end{array}$ \\
\hline $\begin{array}{l}\text { Cultural } \\
\text { differences }\end{array}$ & Corporate & $\begin{array}{l}\text { Anger - } \\
\text { discontent }\end{array}$ & $\begin{array}{l}\text { "..what I have observed many have } \\
\text { personal level issues between Finland and } \\
\text { India, there are cultural differences.. There } \\
\text { is a lack of understanding, because on the } \\
\text { other side there are different procedures } \\
\text { and the problems have escalated..." }\end{array}$ & $\begin{array}{l}\text { Director } 3 \text {, round } 2 \\
\text { autumn } 2007\end{array}$ \\
\hline $\begin{array}{l}\text { Indian } \\
\text { busines s } \\
\text { culture }\end{array}$ & Corporate & $\begin{array}{l}\text { Anger - } \\
\text { discontent }\end{array}$ & $\begin{array}{l}\text { "Well this has remained as a very Indian } \\
\text { organisation.. I would have expected that it } \\
\text { would have become more global, but it } \\
\text { doesn't look like that.." }\end{array}$ & $\begin{array}{l}\text { Director 5, round 2 } \\
\text { autumn } 2007\end{array}$ \\
\hline \begin{tabular}{|l} 
Slow \\
integration
\end{tabular} & Corporate & $\begin{array}{l}\text { Anger - } \\
\text { unfulfilled }\end{array}$ & $\begin{array}{l}\text { "..well maybe I had bigger expectations, } \\
\text { that the India-Finland collaboration and } \\
\text { becoming global would begin faster, and } \\
\text { we could get more new customers and } \\
\text { projects from abroad than we have so far." }\end{array}$ & $\begin{array}{l}\text { Director } 4, \text { round } 2 \\
\text { autumn } 2007\end{array}$ \\
\hline $\begin{array}{l}\text { B ad } \\
\text { integration }\end{array}$ & Corporate & $\begin{array}{l}\text { Anger - } \\
\text { unfulfilled, } \\
\text { discontent }\end{array}$ & $\begin{array}{l}\text { ".. .at least in my opinion the integration } \\
\text { has not succeeded as well as it could } \\
\text { have.." }\end{array}$ & $\begin{array}{l}\text { Account Manager } \\
1, \text { round } 2 \text { autumn } \\
2007\end{array}$ \\
\hline $\begin{array}{l}\text { Change of } \\
\text { company } \\
\text { name }\end{array}$ & Corporate & Anger - irritated & $\begin{array}{l}\text { "..currently I am annoyed that my email } \\
\text { address is xxx.com, because all our } \\
\text { commuication is that we are now "Gamma". } \\
\text { If they ask me now where do I work, I say } \\
\text { Gamma Finland without thinking about it" }\end{array}$ & $\begin{array}{l}\text { Lead Engineer 1, } \\
\text { round } 2 \text { autumn } \\
2007\end{array}$ \\
\hline
\end{tabular}


At time II triggers and emotions emerging from the interviews indicate that the integration process is now clearly progressing and changes are visible; hence we call this the 'reality stage'. Triggers and emotions are related to more concrete issues such as changes in work, organisation, and leadership. Issues related to cultural differences are also emerging, following the increasing interaction between the acquirer and acquired organisation. While positive emotions are slightly more dominant with emotions of happiness and contentment, fears and sadness from time I have changed into anger at time II.

\subsubsection{Emotions at time III - should I stay or should I go}

Two years after the acquisition, the negative emotions represent the larger group with 32 coded negative emotions in comparison to just 14 positive emotions. The range of emotions has narrowed down to contentment, happiness, anger and fear. The positive basic emotions had decreased in number and were either happiness or contentment related to individual level triggers. Contentment and happiness stemmed from work descriptions, successful project work experience with Indian staff and the ability to make a difference in the larger parent company. (See Table 7.) 
Table 7 Positive emotions and triggers two years after the acquisition

\begin{tabular}{|c|c|c|c|c|}
\hline \multicolumn{5}{|c|}{ Positive emotions Time III } \\
\hline Trigger & Source & $\begin{array}{l}\text { Examples of } \\
\text { emotions }\end{array}$ & Intervie w quotes & Interviewee \\
\hline $\begin{array}{l}\text { Successful } \\
\text { project work } \\
\text { experience with } \\
\text { Indians }\end{array}$ & Individual & $\begin{array}{l}\text { Contentment - } \\
\text { contented with } \\
\text { collaboration } \\
\text { with the } \\
\text { Indians }\end{array}$ & $\begin{array}{l}\text { "Well at least in this project completed here, } \\
\text { where we had one Indian involved, we have } \\
\text { been happy about his/her work input.." }\end{array}$ & $\begin{array}{l}\text { Lead Engineer 2, } \\
\text { round } 3 \text { summer } \\
2008\end{array}$ \\
\hline $\begin{array}{l}\text { Challenging } \\
\text { work }\end{array}$ & Individual & $\begin{array}{l}\text { Contentment, } \\
\text { fulfilled }\end{array}$ & $\begin{array}{l}\text { "..I am pretty satisfied, we just need to finalize } \\
\text { the organisational change.. I am happy to the } \\
\text { situation, these challenging tasks. Gamma } \\
\text { Europe will certainly be able to offer me a job } \\
\text { description, which will keep me in the } \\
\text { company. At the moment I have a pretty good } \\
\text { job description, which I am pleased with.." }\end{array}$ & $\begin{array}{l}\text { Engineer } \\
\text { Manager 1, round } \\
3 \text { summer } 2008\end{array}$ \\
\hline $\begin{array}{l}\text { Possibility to } \\
\text { change the } \\
\text { acquirer }\end{array}$ & Individual & $\begin{array}{l}\text { Happiness - } \\
\text { optimistic }\end{array}$ & $\begin{array}{l}\text { "..I still have the opportunity to get Gamma } \\
\text { India to a new direction and to make new } \\
\text { business. That is what I am aiming for and } \\
\text { what motivates into bringing new elements to } \\
\text { the Gamma India business." }\end{array}$ & $\begin{array}{l}\text { Director } 3 \text {, round } \\
3 \text { summer } 2008\end{array}$ \\
\hline
\end{tabular}

Negative emotions were mostly anger related to frustration, discontentment and being unfulfilled. While some perceived their job as being challenging and were content with their job prospects, others were experiencing the opposite. Individual level triggers such as poor job prospects, increased workload and continuous changes in the organisation triggered frustration and irritation in some interviewees. Company-level triggers such as slowness in Indian decision-making, leadership, unclear procedures and lack of resources and support from the acquirer also triggered anger. The integration process had proven slower than expected. Moreover, as an SME Alpha was used to quick and flexible decision-making, but now had to adapt to a larger, slower and more bureaucratic Gamma organisation. Two years since the acquisition the integration process was in many ways completed, but there was a feeling that in some areas there was still work to be done. (See Table 8.) 
Table 8 Negative emotions and triggers at Time III

\begin{tabular}{|c|c|c|c|c|}
\hline \multicolumn{5}{|c|}{ Negative emotions Time III } \\
\hline Trigger & Source & Examples of & Interview quotes & Intervie wee \\
\hline $\begin{array}{l}\text { Poor job } \\
\text { prospects }\end{array}$ & Individual & $\begin{array}{l}\text { Anger - } \\
\text { discontent }\end{array}$ & $\begin{array}{l}\text { "if they are going to diminish the } \\
\text { responsibilities and roles of Sales. What } \\
\text { seems to be the case.. It is going to be in the } \\
\text { new organisational change. It has stlightly } \\
\text { impacted my motivation which shows.. I } \\
\text { have seriously considered a new job, } \\
\text { although within the organisation.." }\end{array}$ & $\begin{array}{l}\text { Account Manager } \\
2 \text {, round } 3 \text { summer } \\
2008\end{array}$ \\
\hline $\begin{array}{l}\text { Increased work } \\
\text { load }\end{array}$ & Individual & $\begin{array}{l}\text { Anger - } \\
\text { fustration }\end{array}$ & $\begin{array}{l}\text { "..well there are certain problems because } \\
\text { I haven't managed to end my sales } \\
\text { responsibilities, so I have those tasks, and } \\
\text { these new responsibilities.. So it is bad that } \\
\text { the roles are not clear... we don't have } \\
\text { enoug staff.." }\end{array}$ & $\begin{array}{l}\text { Account Manager } \\
3 \text {, round } 3 \text { summer } \\
2008\end{array}$ \\
\hline $\begin{array}{l}\text { Changes in the } \\
\text { organis ation }\end{array}$ & Individual & $\begin{array}{l}\text { Anger - } \\
\text { fustration }\end{array}$ & $\begin{array}{l}\text { "..I have started to be a bit sceptical.. } \\
\text { And... ridicule.. A little bit with smile, the } \\
\text { way they conduct organisational change at } \\
\text { Gamma, is that boxes are moved at a higher } \\
\text { level so that everybody obtains a nice, new } \\
\text { position, and then communicate this our } \\
\text { way, but not telling anyone how the boxes } \\
\text { work together, and who belongs to which } \\
\text { box, and every month there is a new } \\
\text { organisation.. I find that at the end they } \\
\text { have no practical relevance, because they } \\
\text { never realise because no one has attempted } \\
\text { to implement them." }\end{array}$ & $\begin{array}{l}\text { Account Manager } \\
1 \text {, round } 3 \text { summer } \\
2008\end{array}$ \\
\hline $\begin{array}{l}\text { Slowness in Indian } \\
\text { decision-making }\end{array}$ & Corporate & $\begin{array}{l}\text { Anger - } \\
\text { discontent }\end{array}$ & $\begin{array}{l}\text { "..decision-making has turned out to be a } \\
\text { disapointment.. Obtaining decisions has } \\
\text { been so byrocratic and difficult.." }\end{array}$ & $\begin{array}{l}\text { Director } 2 \text {, round } 3 \\
\text { summer } 2008\end{array}$ \\
\hline $\begin{array}{l}\text { Leaders hip } \\
\text { (acquirer) }\end{array}$ & Corporate & $\begin{array}{l}\text { Anger - irritated, } \\
\text { fustrated }\end{array}$ & $\begin{array}{l}\text { "..he (the CEO) has started to be fustrated } \\
\text { because of the decision-making... there are } \\
\text { all sorts of pressures, which are in a way } \\
\text { unnecessary..for some reason at least for } \\
\text { indians in this company planning and } \\
\text { organising seems difficult.." }\end{array}$ & $\begin{array}{l}\text { Director } 1 \text {, round } 3 \\
\text { spring } 2008\end{array}$ \\
\hline \begin{tabular}{|l|} 
Unclear \\
proce dures and \\
division of \\
responsibilities
\end{tabular} & Corporate & $\begin{array}{l}\text { Anger - } \\
\text { discontent }\end{array}$ & $\begin{array}{l}\text { "I am disapointed to the integration..we } \\
\text { still operate in Finland according to our } \\
\text { own processes.. The processes are still too } \\
\text { different.." }\end{array}$ & $\begin{array}{l}\text { Account Manager } \\
3 \text {, round } 3 \text { summer } \\
2008\end{array}$ \\
\hline $\begin{array}{l}\text { Acquirer not } \\
\text { showing } \\
\text { commitment and } \\
\text { respect }\end{array}$ & Corporate & $\begin{array}{l}\text { Sadness - } \\
\text { helpless }\end{array}$ & $\begin{array}{l}\text { ".. I wish that both parties would slowly } \\
\text { learn from each other, and appreciate each } \\
\text { other. It goes one direction at the moment, } \\
\text { nothing is accepted from the other } \\
\text { direction...." }\end{array}$ & $\begin{array}{l}\text { Account Manager } \\
1 \text {, round } 3 \text { summer } \\
2008\end{array}$ \\
\hline $\begin{array}{l}\text { Lack of resources } \\
\text { and support from } \\
\text { the acquirer }\end{array}$ & Corporate & $\begin{array}{l}\text { Anger - } \\
\text { discontent, } \\
\text { fustration }\end{array}$ & $\begin{array}{l}\text { "I am very disapointed to business } \\
\text { development, the leadership of this } \\
\text { company and to the Finland-India } \\
\text { collaboration and the resources and } \\
\text { support offered by this company..." }\end{array}$ & $\begin{array}{l}\text { Account Manager } \\
1 \text {, round } 3 \text { summer } \\
2008\end{array}$ \\
\hline
\end{tabular}


At time III emotions were strongly negative and mostly angry. There was a great deal of frustration stemming from the integration process, organisational changes and a different way of doing things. It is clear that the acculturation process was on-going (Cartwright \& Cooper, 1993). As the two-year contractual time some interviewees were tied to was coming to an end, we call this point the 'should I stay or should I go' stage. Many interviewees were trying to find their place in the new organization, sometimes in new positions following the organisational changes, while some had decided to leave the organisation. Out of the thirteen panel interviewees four left the organisation shortly after the last interviews. In the next section we discuss the behavioural outcomes of emotions in more depth.

\subsection{Behavioural outcomes of emotions during post-M\&A integration}

Despite the various experienced emotions, the outcomes were much more limited. The results imply that key persons may have difficulties in acting upon their emotions. For example, some expressed their willingness to leave the organisation (i.e. turnover intention) a little over a year post-acquisition during the round two interviews (in autumn 2007), yet they were retained on a two-year contract until summer 2008. The contract contained severe monetary sanctions if the managers or key persons were to leave before the agreed time. The contract was perceived negatively, as a stick, while few or no carrots were offered. This made it difficult to analyse the true outcomes related to emotions (cf. Kustatscher \& Cooper, 2005; Sinkovics et al., 2011). Based on the empirical evidence, the outcomes were related in general to negative emotions. Emotions of anger, frustration and discontentment led to decreased motivation, increased turnover intention and lower organisational commitment. Positive emotions such as pride led to increased organisational identification. Happiness about finding the right acquirer inspired one interviewee to learn more about Indian culture. (See Table 9.) 
Table 9 Emotions and outcomes

\begin{tabular}{|c|c|c|c|}
\hline Positive emotion & Outcome & Examples & Source \\
\hline $\begin{array}{l}\text { Happiness - } \\
\text { enthusiastic }\end{array}$ & $\begin{array}{l}\text { motivation to learn } \\
\text { about the Indian } \\
\text { culture }\end{array}$ & $\begin{array}{l}\text { "..it felt straight away as the right } \\
\text { company and as I have talked with him, } \\
\text { listened to his speeches about company } \\
\text { values, learned more and he cites Gandhi } \\
\text { in many things... he has read a lot about } \\
\text { Gandhi and cites his texts so I have } \\
\text { started to read it.." }\end{array}$ & $\begin{array}{l}\text { Director } 2, \text { round } 1 \\
\text { spring } 2007\end{array}$ \\
\hline Happiness - fulfilled & job satisfaction & $\begin{array}{l}\text { "..well those above mentioned tasks..if I } \\
\text { can carry on with them and keep doing } \\
\text { them fine, and of course if we get new } \\
\text { interesting projects that would keep me } \\
\text { satisfied in this organisation.." }\end{array}$ & $\begin{array}{l}\text { Engineer Manager } 2, \\
\text { round } 2 \text { autumn } 2007\end{array}$ \\
\hline Negative e motion & Outcome & Examples & Source \\
\hline Anger - unfulfilled & $\begin{array}{l}\text { low motivation } \\
\text { low motivation and } \\
\text { turnover }\end{array}$ & $\begin{array}{l}\text { "..the integration has not proceeded as I } \\
\text { hoped, and last winter, last spring and } \\
\text { summer has been a period of lower } \\
\text { motivation..." } \\
\text { "..my motivation has been low.. And in } \\
\text { fact I have resigned.." }\end{array}$ & $\begin{array}{l}\text { Director 2, round } 2 \\
\text { autumn } 2007 \\
\text { Lead Engineer 1, round } \\
3 \text { summer } 2008\end{array}$ \\
\hline $\begin{array}{l}\text { Anger - } \\
\text { discontentment }\end{array}$ & turnover intentions & $\begin{array}{l}\text { "..regarding my career, I can't see that } \\
\text { there is a very long career for me here at } \\
\text { Gamma..." }\end{array}$ & $\begin{array}{l}\text { Lead Engineer 2, round } \\
3 \text { summer } 2008\end{array}$ \\
\hline Anger - fustrated & $\begin{array}{l}\text { lower commitment / } \\
\text { identification }\end{array}$ & $\begin{array}{l}\text { "..The most difficult thing here at location } \\
x \text { is that I have my office here buyt I have } \\
\text { invitations to steering groups and such, } \\
\text { and I just don't have time for life here at } \\
x, \text { it has really disturbed my work, but it } \\
\text { hasn't of course diminished my } \\
\text { commitment to this company, but it has } \\
\text { clearly diminished my sense of } \\
\text { belonging..." }\end{array}$ & $\begin{array}{l}\text { Account Manager } 3, \\
\text { round } 2 \text { autumn } 2007\end{array}$ \\
\hline Anger - unfulfilled & $\begin{array}{l}\text { lower } \\
\text { organis ational } \\
\text { identification }\end{array}$ & $\begin{array}{l}\text { "..it was then a more Finnish firm, for } \\
\text { example our company was ranked in the } \\
\text { Finnish Magazine Kauppalehti as one of } \\
\text { the best companies in Finland in terms of } \\
\text { growth and profitability, which then made } \\
\text { me proud..one identifies itself as part of a } \\
\text { successful firm, creating success... I don't } \\
\text { experience the same for Gamma India.." }\end{array}$ & $\begin{array}{l}\text { Account Manager 1, } \\
\text { round } 2 \text { autumn } 2007\end{array}$ \\
\hline
\end{tabular}

Out of the thirteen interviewees, four had left by the time their retention contract ended in summer 2008. In fact, the CEO left the company due to personal reasons slightly earlier 
than initially agreed in autumn 2007 by mutual agreement with the Indian acquirer. There was discontentment regarding how the company was being managed and frustration resulting from the lack of decision-making and increasing loss of power increasing. It should be noted that the founders of the company had an entrepreneurial spirit and were extremely proud to have grown their business from just a couple of founders to over 300 employees.

In summary, emotions had various outcomes, but top managers were restricted in the ways in which they could react to their emotions. The interviewees with negative emotions displayed lower job satisfaction, commitment and motivation. The contractual agreement retained the top managers for two years and while some were happy and motivated by the new international projects, some interviewees admitted experiencing turnover intentions some time before they were actually able to leave.

\subsection{Emotional experience during the post-M\&A integration stage}

To obtain a deeper understanding of emotional experience during the M\&A integration stage, we used visualisation techniques to illustrate the different emotional journeys of our interviewees (cf. Langley, 1999). The emotional journeys are based on numerous emotions processes following cognitive appraisal theory and affective event theory. Accordingly, each emotion is triggered by an event and emotions may lead to a behavioural outcome (e.g. Sinkovich et al., 2011). It is important to notice that emotions do not always lead to a behavioural outcome. In the Appendix, Figures A3-A6 illustrate the emotional experience of four interviewees (interviewees 3, 5, 9 and 10). These journeys are very different. Interviewee 3 experiences emotional ambivalence (both positive and negative emotions) throughout the integration process, while interviewees 5 and 10 change from being quite happy at time I, to experiencing only anger by time III. Interviewee 9 is content and happy throughout the integration process. 
Our analysis revealed three interesting findings. First, Figures A3-A6 demonstrate well how interviewees may experience various positive and negative basic emotions simultaneously (see e.g. Interviewees 3 and 5). Second, in some cases the behavioural outcome becomes a trigger, which either reinforces an emotion in the specific time period or reaches over to another time period. For example, interviewee 9 experienced happiness from various triggers at time II which made him work more and experience success. The experience of success became a trigger for more happiness, i.e. a self-reinforcing cycle. In addition, the emotion of happiness at time II also lead him to share and give ideas and suggestions to the acquirer (behavioural outcome). This outcome became a trigger in time III, where 'changing the acquirer' i.e. business and organisation development triggered happiness in the interviewee. Finally, our visual emotional journeys demonstrate how some triggers 'carry through' to different time periods. For example, in the emotional journey of interviewee 3 (see Figure A3), the arrow with a dash line illustrates how the trigger 'loss of decision making power' at time I occurs at time III as 'Indian decision-making'. This demonstrates the different stages of the integration process; at time I 'losing decision-making power', which triggers sadness related to selling the company, is about the interviewee. At time III 'Indian decision-making' is clearly about the acquirer having the decision-making power. In general, these triggers which carry through from one time period to another evoke the same emotion (see for example interviewees 3 and 5). Nonetheless, in some cases a trigger to a positive emotion can become a trigger to a negative emotion. For example, 'career prospects' evokes happiness in interviewee 10 at time II, while unfulfilled career prospects i.e. 'slower career development than expected' evokes anger at time III.

\section{Discussion}


This study reveals the wide array of emotions that top managers may experience during M\&As (cf. Kiefer, 2002). The findings demonstrate how top managers experienced nearly all eight basic negative and positive emotions (cf. Laros \& Steenkamp, 2005), sometimes simultaneously (cf. Kiefer, 2002). Accordingly, any one individual can experience simultaneously, for example, happiness about the deal being completed and fears about job security. Our findings imply that M\&As trigger not only negative but various positive emotions during the post-M\&A integration stage. The acquisition allowed the Finnish IT SME to survive in an increasingly competitive market, but also provided opportunities to grow and expand internationally.

Literature suggests that employee emotions are triggered by how they experience and appraise M\&A-related features and events in relation to their work and job (cf. Kusstatscher \& Cooper, 2005; Sinkovics et al., 2011). However, our findings imply that events triggering emotions can be divided into individual-level and company-level triggers. Company-level triggers represented an important share. Our findings imply that top managers and key persons can have emotions triggered by the "well-being" of the company and not only by something directly related to them. This accentuates the particular role of top managers and especially founders of SMEs who truly care for the future of their organisation, and/or who naturally consider the 'bigger picture' or 'greater good' due to their position. In addition, our research demonstrates that triggers can lead to a very different appraisal depending on the individual. For one 'selling the ownership' triggered happiness, while for another individual 'selling one's life's work' triggered sadness. The appraisal also changed over time. For example, 'future prospects' triggered happiness at time I, but two years' post-acquisition, it triggered fear and anger as the interviewees felt that the M\&A had not lived up to expectations. 
Consequently, one trigger can lead to very different behavioural outcomes depending whether it evokes positive or negative emotions. Understanding the appraisal process (cf. Lazarus, 1993), how individual- and company-level M\&A events trigger emotions in individuals, can enable acquirers to design much more efficient retention packages. In line with prior research top managers and key persons demonstrated fewer feelings of insecurity but higher turnover intentions (cf. Gunkel et al., 2015). Based on our findings, the retention contract did prevent the top managers from leaving early but did not stop them from experiencing negative outcomes such as increased turnover intentions, lower commitment and decreased motivation and job satisfaction. This can be particularly critical in terms of emotional contagion, collective affective appraisal (cf. Barsade, 2002; Gooty et al., 2010; Kaplan et al., 2014), emotions convergence and group emotions (Menges \& Kilduff, 2015)

While it is impossible to form a continuous picture of how emotions developed over the two years, the findings suggest that in this case, the proportion of positive emotions was higher up to one-year post-acquisition, and negative emotions represented a much larger proportion afterwards. An acquisition is often followed by a honeymoon period (e.g. Cartwright \& Cooper, 1992), which might explain the initial positive emotions. However, it has been argued that the acculturation process (contact, conflict and adaptation) can take years following an M\&A (cf. Cartwright \& Cooper, 1993) and post-M\&A integration is often related to 'merger syndrome' (e.g. Kusstatcher \& Cooper, 2005) which may explain the surge of negative emotions two years after the acquisition in this case. Negative emotions at time III reflected anger towards the integration process, which was perceived as slower than anticipated, and expectations regarding the acquisition and individual career prospects which were unfulfilled. This is in line with prior research on managing employees' expectations in M\&As (Hubbard \& Purcell, 2001). Finally, this study highlights the differences between 
people; it is important to note that individual emotional journeys may differ greatly (see Figures A3-A6 in the Appendix; cf. Verduyn et al., 2009).

\section{Conclusions}

Recent empirical research has begun to focus on the role of emotions in M\&As. However, research in this field is still scarce and much of it focuses on employees (cf. Kusstatscher \& Cooper, 2005; Sinkovics et al., 2011; Gunkel et al., 2015), with only a few studies focusing on managers (e.g. Durand, 2016; Reus, 2012; Vince, 2006). The main purpose of our research is to focus on the emotional experience of top managers and key persons of the acquired company by focusing on the emotion process.

\subsection{Theoretical implications}

This research is inspired by Kiefer (2002) work on emotional experience during mergers, and contributes by expanding Sinkovics et al.'s (2011) and Zagelmeyer et al.'s (2016) work. First, our study demonstrates that emotions can result from both individual-level and companylevel triggers. This distinction can enhance future research on different events and triggers as well as obtaining a better understanding of the appraisal process in different groups (white and blue collars). Traditionally, the focus has been on the 'merger syndrome', the negative emotions evoked by M\&As in employees (cf. Gunkel et al., 2015, Kusstatcher \& Cooper, 2005; Sinkovics et al., 2011; Vince, 2006). Our empirical evidence shows how top managers and key persons experienced nearly all eight basic emotions (cf. Laros \& Steenkamp, 2005), sometimes simultaneously (cf. Kiefer, 2002). Our findings strongly imply that M\&As are very emotional in a broad and diverse manner not only to employees but also to top managers and other key persons. Emotion research has shown that positive emotions are useful in organisations and valuable assets in the workplace (Ashkanasy et al., 2017). However, recent 
research posits that negative emotions can be useful for example to survive under certain circumstances. This research contributes to Sinkovics et al. (2011) and Zagelmeyer et al. (2016) but also to the field of emotion research and research on the interplay between negative and positive emotions. (Ashkanasy et al., 2017.)

Nevertheless, the most important contribution to the work of Sinkovics et al. (2011) and Zagelmeyer et al. (2016), and to emotion research more broadly, is the longitudinal aspect of our research. This longitudinal single case study reveals the complexity regarding the appraisal of various events during the post-acquisition integration stage. There is limited theoretical development regarding the dynamic nature of emotions in dominant theories of emotions, such as basic emotion and core affect theories (Sacharin, Sander \& Scherer, 2012; Verduyn et al. 2009). Our visual emotional experience journeys reveal the interesting role emotion triggers play in how individuals appraise different events during the M\&A. A trigger, evoking a positive emotion in the early stage of the post-M\&A integration stage, may evoke a negative appraisal later in the process. There is clearly a temporal dimension to appraisal.

Moreover, our empirical data provides evidence of Fredrickson's broaden-and-build theory of positive emotions (Fredrickson, 2013) and of the dynamic emotional process model (Oh \& Farh, 2017). Our findings provide also support to Scherer (2009) who defines emotion as an emergent, dynamic process based on the individual subjective, cognitive appraisal of an affective event. Emotion processes are dynamically integrated over time: appraisal influences emotion, but the resulting emotion influences the later appraisal reciprocally (Lazarus 1991; Scherer, 2009). Hence, despite their episodic nature, emotions are dynamic due to the interrelated and integrated relationship between episodes. Emotions are emergent as they cannot be predicted from prior episodes or experiences (c.f. Garud et al., 2015). Our data 
offers evidence that appraisals and responses from one episode carry forward to serve as inputs for the next episode (see Appendix Interviewee 9 in Figure A5).

Finally, the longitudinal nature of our study reveals that emotions can peak two years from the acquisition. This finding supports prior research on acculturation process and postM\&A identification by providing a deeper understanding of why it may take years to build a joint culture (e.g. Cartwrigth \& Cooper, 1993).

\subsection{Managerial implications}

This research makes a number of contributions to practitioners. A large proportion of M\&A literature focuses on the 'merger syndrome' associated with employees (cf. Kusstatscher \& Cooper, 2005; Sinkovics et al., 2011) and this research makes an important managerial contribution by focusing on top managers and key persons. Our findings suggest that top managers and key persons are very emotional and although retention contracts provide an effective way to retain those key knowledge workers over the critical integration period, they do not prevent top managers and key persons from experiencing sometimes high turnover intentions. Being forced to stay when emotions and attitudes deteriorate, together with increasing emotional labour, which may require faking an unfelt emotion or supressing an inappropriate felt emotion (cf. Diefendorff \& Gosserand, 2003), can be very counterproductive for the individual and the organisation.

This research demonstrates that by obtaining a better understanding of managers and other key persons' emotions, it is easier to identify the right leaders with a positive attitude towards stressful organisational events such as M\&As. Focusing on positive emotions and fostering a positive emotional climate is essential during the post-M\&A integration stage (cf. Huy, 2002; Kusstatscher, 2006). However, as mentioned earlier negative emotions should not be dismissed, as negative emotions can also trigger positive outcomes (e.g. Ashkanasy et al., 
2017; Graebner, Heimeriks, Huy \& Vaara, 2017; Sarala et al., in press). Negative emotions carry adaptive significance in the moment (for example shock when hearing about the acquisition for the first time and immediate fear of losing one's job), but positive emotions carry adaptive significance on longer timescales (for example happiness about future career prospects in the new organisation) (Fredrickson, 2013). Nevertheless, negative emotions can be harmful from an "emotional contagion" perspective, which could potentially lead to collective negative emotions (cf. Barsade, 2002; Elfenbein, 2014). Hence, instead of focusing on negative or positive emotions per se, it is important to manage the emotional experience during the integration process to avoid various emotional and behavioural reactions that might jeopardise the successful completion of the M\&A (cf. Ager, 2011). The key is the appropriate balance of both positive and negative emotions (Fredrickson, 2013). Moreover, our findings reveal that some top managers and key persons experienced both positive and negative emotions, emotional ambivalence, in some or all time periods. Recent research argues that emotional complexity represents a more developed reaction to complex change events than emotional simplicity, i.e. just feeling 'positive' or 'negative'. Accordingly, emotional complexity could help enhance leadership of change (e.g. Ashkanasy et al., 2017; Rothman \& Melwani, 2017).

\subsection{Limitations and future research orientation}

This research has some limitations. First, this study, as a single case study, should be interpreted within its context. However, single case studies can be powerful examples (cf. Siggelkow, 2007). To truly understand emotion, it is important to contextualise the findings. Emotions were analysed in the context of work-related attitudes and the post-acquisition integration stage. This approach has its limitations in terms of the context in which each emotion occurs and what the target of the emotion is. This can however be an advantage, as 
emotions can be difficult to discuss explicitly and abstractly. The third limitation relates to the challenges inherent in studying emotions; instead of imposing emotion categories on interviewees, we relied on self-reported verbal expressions of emotions that seemed to suit best in terms of capturing distinct emotions in a complex setting (Dasborough, Sinclair, Russell-Bennett, \& Tombs, 2008; Robinson \& Clore, 2002) and this naturally increases the risk of subjective bias in the analysis. The fourth limitation is related to the gender bias. All the interviewees were Finnish, male engineers. The interviewees were representative of the case company, which was male dominated, but there is a need to understand the role of gender in emotional experiences. Finally, the data-collection period was framed according to the key informants, namely top managers, who had to sign a two-year contract agreeing to remain in the organisation and hence would also be available for the research. This proved to enrich our data and our ability to analyse the applicability of the conceptual framework proposed by Sinkovics et al. (2011) in a different setting, yet it rendered the identification of outcomes slightly more difficult.

While this study gave important insights into what emotions top managers and key persons experience in an international M\&A setting, we have only scratched the surface. Firstly, this study examined a friendly acquisition. Within the field of M\&As, it is also important to study the emotions of top managers and key persons undergoing hostile acquisitions or mergers of equals. Secondly, this study focused on the emotional journey/experience of top managers and key persons, some which were retained through a two-year contract. The behavioural responses of top managers and key persons were limited due to the retention contracts, but also due to their position. There is a need to focus more on emotional labour processes of top managers, i.e. how they manage their own emotions, during major organisational events such as M\&A (e.g. Diefendorf \& Gosserand, 2003; Ashkanasy et al., 2017; Graebner et al., 2017). There is also a need to obtain a better 
understanding of emotional experiences and subjective emotional intensity during major organisational events such as M\&As. Focusing on specific emotional episodes during the integration process, and emotional intensity during these episodes, would provide a deeper understanding of emotions and how to manage them during post-M\&A integration. (cf. Verduyn et al., 2009). Recent research has revealed that negative emotions can also play a positive role. It has also been suggested, that negative emotions among acquiring firm personnel could also conceivably engender positive organisational outcomes (Graebner et al., 2017). There is a lack of theoretical framework enabling us to understand the processes underlying this paradoxical situation (cf. Ashkanasy et al., 2017).

In addition, due to the longitudinal approach our study has some processual elements. However, there is a call for studies adopting a process study approach (e.g. Langley, 1999) to obtain a deeper understanding of the underlying emotion processes or episodes and their interconnections (cf. Holmlund, 2004; Tian et al., in press). The episodic emotional process model considers how appraisals, emotions and responses from one episode carry forward to serve as inputs for the next in feedback loops marked by 'conscious learning', as well as in less conscious feedback loops (Oh \& Farh, 2017). Future research would benefit from more research on the role emotions play in post-M\&A identification building, socio-cultural integration, and how emotional expressions vary across cultures (Graebner et al., 2017; Sarala et al., in press). Accordingly, cross-border M\&As provide a fruitful research context for emotions.

Additionally, since this study focused on the target company, further work could study both companies during the M\&A process more closely to compare the top managers' emotional experiences in the acquiring (parent) and acquired (target) company. Identifying emotions and understanding the various triggers can be difficult in an international context. This research focused on an acquired medium-sized company, but more research is needed in 
the International Business field to understand emotions in Multinational Enterprises (MNEs). In addition, there is little understanding regarding the role of emotions in the dynamic between a company from an emerging economy and a company from a developed economy. Moreover, there is need for new methodological approaches for example experimental methods, physiological measurements, ethnography or autoethnography (cf. Ashkanasy et al., 2017). Technological advancements enable more adequate and accurate measurements of emotions through various emotion-tracker apps and devices. Using multiple methods might produce a more accurate understanding of what triggers emotions during post-M\&A integration. Furthermore, individual variance may be due to the different profiles (founders, minority shareholders, and non-owners). A quantitative research approach would enable to analyse similarities and differences between groups.

It has been argued that emotions can emerge at higher levels referring to group emotions, referring to processes of interaction by which people pass on emotions to each other and make sense together of emotion-eliciting events, leading to emotion convergence (Menges \& Kilduff, 2015). However, this research was conducted at the individual level, and based on our findings top managers and key persons varied greatly in their emotional experience. This would suggest that there would be less emotions convergence higher in the organisation hierarchy. More research is needed in emotions convergence and group emotions in the context of (cross-border) M\&As in different groups (e.g. blue, white collar, mixed) (cf. Menges \& Kilduff, 2015).

Finally, previous studies have shown that there are strong cultural differences in the experiencing and expression of emotions (cf. Eid \& Diener, 2001). This research demonstrated that the cultural differences between the acquirer and the acquired company were a source of emotional distress; future studies could analyse the role of cultural 
differences in managing emotions in cross-border acquisitions (e.g. Sarala et al., in press). Hopefully, this paper will inspire more research in this field.

\section{Acknowledgements}

We wish to warmly thank the reviewers, colleagues, conference and seminar participants for their helpful comments and discussion related to earlier versions of this paper presented at AIB UKI conference and several research seminars. We are also indebted to the two anonymous reviewers for their constructive, encouraging and inspiring feedback, which helped us to improve the article. We also grateful for the financial support provided from Finnish Funding Agency for Innovation for the project 26003235 and the Academy of Finland for project 26080068.

\section{References}

Ager, D.L. (2011). The Emotional Impact and Behavioral Consequences of Post-M\&A Integration: An Ethnographic Case Study in the Software Industry. Journal of Contemporary Ethnography, 40(2), 199-230.

Angwin, D.N. \& Meadows, M. (2015). New Integration Strategies for Post-Acquisition Management. Long Range Planning, 48(4), 1-17.

Ashkanasy, N.M., \& Daus, C.S. (2002). Emotion in the workplace: The new challenge for managers. Academy of Management Perspectives, 16(1), 76-86.

Ashkanasy, N., \& Humphrey, R.H. (2011). Current Emotion Research in Organizational Behavior. Emotion Review, 3(2), 214-224.

Ashkanasy, N.M., Humphrey, R.H., \& Huy, Q.N. (2017). Integrating emotions and affect in theories of management. Academy of Management Review, 42(2), 175-189. 
Bagozzi, R.P., Gopinath, M., \& Nyer, P.U. (1999). The role of emotions in marketing. Journal of the academy of marketing science, 27(2), 184-206.

Balahur, A., Hermida, J.M., \& Montoyo, A. (2012). Detecting implicit expressions of emotion in text: A comparative analysis. Decision Support Systems, 53(4), 742-753.

Barsade, S.G. (2002). The ripple effect: emotional contagion and its influence on group behavior. Administrative Science Quarterly, 47(4), 644-675.

Bartel, C.A., \& Saavedra, R. (2000). The Collective Construction of Work Group Moods. Administrative Science Quarterly, 45(2), 197-231.

Brebner, J. (2003). Gender and emotions. Personality and Individual Differences. 34(3), 387394.

Carrera, P., \& Oceja, L. (2007). Drawing mixed emotions: Sequential or simultaneous experiences? Cognition and Emotion, 21(2), 422-441.

Cartwright, S., \& Cooper, C.L. (1992). Mergers and acquisitions, the human factor. Oxford: Butterworth-Heinemann Ltd.

Cartwright, S., \& Cooper, C. (1993). The role of culture compatibility in successful organizational marriage. Academy of Management Executive, 7(2), 57-70.

Cartwright, S., \& Schoenberg, R. (2006). Thirty years of mergers and acquisitions research: recent advancement and future opportunities. British Journal of Management, 17(S1), S1-S5.

Chmiel, A., Sienkiewicz, J., Thelwall, M., Paltoglou, G., Buckley, K., Kappas, A., \& Holyst, J.A. (2011). Collective Emotions Online and Their Influence on Community Life. PloS ONE, 6(7), 1-8.

Clarke, N., \& Salleh, N. M. (2011). Emotions and their management during a merger in Brunei. Human Resource Development International, 14(3), 291-304. 
Daniels, J.D., \& Cannice, M.V. (2004). Interview studies in international business research, In: Marshan-Piekkari, R. and Welch, C. (Eds.), Handbook of Qualitative Research Methods for International Business, Cheltenham, UK: Edward Elgar.

Dasborough, M.T., Sinclair, M., Russell-Bennett, R., and Tombs, A. (2008). Measuring emotion: methodological issues and alternatives. In N.M. Ashkanasy \& C.L. Cooper (Eds.), Research Companion to Emotion in Organizations (pp. 197-208). Cheltenham: Edward Elgar.

Diefendorff, J., \& Gosserand, R. H. (2003). Understanding the emotional labor process: a control theory perspective. Journal of Organizational Behavior, 24, 945-959.

Duclos, S.E., Laird, J.D., Schneider, E., Sexter, M., Stern, L., \& Van Lighten, O. (1989). Emotion-Specific Effects of Facial Expressions and Postures on Emotional Experience. Journal of Personality and Social Psychology, 57(1), 100-108.

Durand, M. (2016). Employing critical incident technique as one way to display the hidden aspects of post-merger integration. International Business Review, 25, 87-102.

Eid, M., and Diener, E. (2001). Norms for Expressing Emotions in Different Cultures: Interand Intranational Differences. Journal of Personality and Social Psychology, 81(5), $869-885$.

Eisenhardt, K.M. (1989). Building theories from case study research. Academy of Management Review, 14(4), 532-550.

Elfenbein, H.A. (2014). The many faces of emotional contagion: an affective process theory of affective linkage. Organizational Psychology Review, 1-37.

Elpidorou, A. \& Freeman, L. (2014). The Phenomenology and Science of Emotions: An introduction. Phenomenology and the Cognitive Sciences, 13(4), 507-511. 
Filipowicz, A., Barsade, S., and Melwani, S. (2011). Understanding Emotional Transitions: The Interpersonal Consequences of Changing Emotions in Negotiations. Journal of Personality and Social Psychology, 101(3), 541-556.

Fredrickson, B.L. (2013). Positive emotions broaden and build. In P. Devine, \& A. Plant (Eds.), Advances in Experimental Social Psychology (pp. 1-53), Vol. 47. Burlington: Academic Press.

Frijda, N.H. (1987). Emotion, cognitive structure, and action tendency. Cognition and Emotion, 1, 115-143.

Frijda, N.H. (1993). Moods, emotion episodes, and emotions. In M. Lewis, \& J.M. Haviland, (Eds.), Handbook of Emotions (pp. 381-403). New York: Guildford.

Garud, R., Simpson, B., Langley, A., \& Tsoukas, H. (2015). How does novelty emerge? In Garud, R., Simpson, B., Langley, A. \& Tsoukas, H. (Eds.), The emergence of novelty in organizations (27-55). Oxford: Oxford University Press.

Gioia, D.A., Corley, K.G., \& Hamilton, A.L. (2013). Seeking qualitative rigor in inductive research: notes on the Gioia Methodology. Organisational Research Methods, 16, 1531.

Gooty, J., Connelly, S., Griffith, J., \& Gupta, A. (2010). Leadership, affect, and emotions: A state of the science review. The Leadership Quarterly, 21, 979-1004.

Graebner, M.E., Heimeriks, K.H., Huy, Q.N. \& Vaara, E. (2017). The process of post-merger integration: a review and agenda for future research. Academy of Management Annals, 11(1), 1-32.

Gunkel, M., Schlaegel, G., Rossteutscher, R., \& Wolff, B. (2015). The human aspect of cross-border acquisition outcomes: the role of management practices, employee emotions, and national culture. International Business Review, 24(3), 394-408. 
Haspeslagh, P. C. \& Jemison, D. B. (1991). Managing acquisitions - creating value through corporate renewal. The Free Press: New York.

Holmlund, M. (2004). Analyzing business relationships and distinguishing different interaction levels. Industrial Marketing Management, 33(4), 279-287.

Hubbard, N., \& Purcell, J. (2001). Managing employee expectations during acquisitions. Human Resource Management Journal, 11(2), 17-33.

Huy, Q.N. (2002). Emotional balancing of organizational continuity and radical change: The contribution of middle managers. Administrative Science Quarterly, 47(1), 31-69.

Huy, Q.N. (2012). Emotions in strategic organization: Opportunities for impactful research. Strategic Organization, 10(3), 240-247.

Jagersma, P.K. (2005). Cross-border acquisitions of European multinationals. Journal of General Management, 30(3), 13-34.

Jemison, D. B. \& Sitkin, S. B. (1986). Corporate Acquisitions: A process perspective. Academy of Management Review, 11(1), 145-163.

Kaplan, S., Cortina, K., Ruark, G., LaPorte, K., \& Nicolaides, V. (2014). The role of organizational leaders in employee emotion management: A theoretical model. The Leadership Quarterly, 25, 563-580.

Kiefer, T. (2002). Understanding the emotional experience of organizational change: Evidence from a merger. Advances in Developing Human Resources, 4, 39-61.

King, D., Dalton, D., Daily, C., \& Covin, J. (2004). Meta-analyses of post-acquisition performance: indications of unidentified moderators. Strategic Management Journal, 25(2), 187-200.

Khan, Z., Soundararajan, V., Wood, G., \& Ahammad, M.F. (in press). Employee emotional resilience during post-merger integration across national boundaries: Rewards and the mediating role of fairness norms. Journal of World Business. 
Krug, J.A., \& Hegarty, H. W. (2001). Predicting who stays and leaves after an acquisition: A study of top managers in multinational firms. Strategic Management Journal, 22(2), $185-196$.

Kusstatscher, V., \& Cooper, C.L. (2005). Managing emotions in mergers and acquisitions. Cheltenham: Edward Elgar Publishing Ltd.

Kusstatscher, V. (2006). Cultivating positive emotions in mergers and acquisitions. Advances in Mergers and Acquisitions, 5, 91-103.

Kvale, S. (1996). InterViews: An introduction to qualitative research interviewing. Thousand Oaks, California: Sage Publications, Inc.

Lander, M.W., \& Kooning, L. (2013). Boarding the aircraft: trust development amongst negotiators of a complex merger. Journal of Management Studies, 50(1), 1-30.

Langley A. (1999). Strategies for Theorizing from Process Data. The Academy of Management Review, 24(4), 691-790.

Laros, F. J.M., \& Steenkamp, J.B. E.M. (2005). Emotions in consumer behaviour: a hierarchical approach. Journal of Business Research, 58(10), 1437-1445.

Larsen, R.J., Augustine, A.A., \& Prizmic, Z. (2009). A process approach to emotion and personality: Using time as a facet of data. Cognition and Emotion, 23(7), 1407-1426.

Lazarus, R. S. (1991). Emotion \& Adaptation. Oxford University Press: New York, USA.

Lazarus, R.S. (1993). From psychological stress to emotions: A history of changing outlooks. Annual Review Psychology, 44, 1-21.

Lincoln, J.R., \& Cuba, E.G. (1985). Naturalistic Inquiry. Sage Publications: Beverly Hills.

Marks, M. L., \& Mirvis, P. H. (2001). Making mergers and acquisitions work: Strategic and psychological preparation. Academy of Management Executive, 15, 80-92. 
Menges, J. I. \& Kilduff, M. (2015). Group Emotions: Cutting the Gordian Knots Concerning Terms, Levels of Analysis, and Processes. The Academy of Management Annals, 9(1), 845-928.

Mudambi, R., Piscitello, L., \& Rabbiosi, L. (2014). Reverse knowledge transfer in MNEs: Subsidiary innovativeness and entry modes. Long Range Planning, 47, 49-63.

Mulligan, K., \& Scherer, K.R. (2012). Towards a working definition of emotion. Emotion Review, 4(4), 345-357.

Oh, J.K., \& Farh, C.I.C. (2017). An emotional process theory of how subordinates appraise, experience, and respond to abusive supervision over time. Academy of Management Review, 42(2), 207-232.

Pettigrew, A.M. (1990). Longitudinal field research on change: theory and practice. Organizational Science, 1(3), 267-292.

Rabbiosi, L. (2011). Subsidiary roles and reverse knowledge transfer: an investigation of the effects of coordination mechanisms. Journal of International Management, 17, 97-113.

Ranft, A.L., \& Lord, M.D. (2002). Acquiring new technologies and capabilities: A grounded model of acquisition implementation. Organization Science, 13(4), 420-441.

Rank, J., \& Frese, C. (2008). The impact of emotions, moods, and other affect-related variables on creativity, innovation and initiative. In Ashkanasy, N.M., \& C.L. Cooper (Eds), Research Companion to Emotion in Organizations (pp. 103-119). Cheltenham: Edward Elgar.

Reus, T.C. (2012). Culture's consequences for emotional attending during cross-border acquisition implementation. Journal of World Business, 47, 342-351.

Robinson, M.D., \& Clore, G.L. (2002). Belief and Feeling: Evidence for an Accessibility Model of Emotional Self-Report. Psychological Bulletin, 128(6), 934-960.

Roseman, I. J., Spindel, M. S., \& Jose, P. E. (1990). Appraisals of emotion-eliciting events: 
testing a theory of discrete emotions. Journal of Personality and Social Psychology, 59(5), 899-915.

Rothman, N.B., \& Melwani, S. (2017). Feeling mixed, ambivalent, and in the flux: the social functions of emotional complexity for leaders. Academy of Management Review, 42(2), 259-282.

Sacharin, V., Sander, D. \& Scherer, K.R. (2012). The perception of changing emotion expressions. Cognition and Emotions, 26(7), 1273-1300.

Sarala, R. M., Vaara, E. \& Junni, P. (in press). Beyond merger syndrome and cultural differences: New avenues for research on the "human side" of global mergers and acquisitions (M\&As). Journal of World Business, $\mathrm{xx}(\mathrm{xx}), \mathrm{xx}-\mathrm{xx}$.

Scherer, K. R. (2009). The dynamic architecture of emotion: Evidence for the component process model. Cognition and Emotion, 23(7), 1307-1351.

Schoenberg, R. (2006). Measuring the performance of corporate acquisition: an empirical comparison of alternative metrics. British Journal of Management, 17(4), 361-370.

Sieben, B., \& Wettergren, A. (Eds.) (2010). Emotionalizing organizations and organizing emotions. Houndmills: Palgrave Macmillan.

Siggelkow, N. (2007). Persuasion with case studies. Academy of Management Journal, 50(1), $20-24$

Sinkovics, R.R., Zagelmeyer, S., \& Kusstatscher, V. (2011). Between merger and syndrome: The intermediary role of emotions in four cross-border M\&As. International Business Review, 20(1), 27-47.

Sinkovics, R.R.\& Alfoldi, E.A. (2012). Progressive focusing and trustworthiness in qualitative research. The enabling role of computer-assisted qualitative data analysis software (CAQDAS). Management of International Review, 52(6), 817-845. 
Sinkovics, R.R., Penz, E., \& Ghauri, P.N. (2008). Enhancing the trustworthiness of qualitative research in international business. Management International Review, 48(6), $689-714$.

Solomon, R.C. (2008). The Philosophy of Emotions. In Lewis M., \& J.M. Haviland (Eds.), Handbook of Emotions (pp. 3-16). New York: Guildford.

Soscia, I. (2013). Emotions and Consumption Behaviour. Cheltenham: Edward Elgar.

Stake, R. E. (1995). The Art of Case Study Research. California: Sage Publications.

Stahl, G. \& Voigt, A. (2008). Do Cultural Differences Matter in Mergers and Acquisitions? A Tentative Model and Examination. Organization Science, 19(1),60-176.

Sy, T., Côté, S., \& Saavedra, R. (2005). The contagious leader: Impact of the leader's mood on the mood of group members, group affective tone, and group processes. Journal of Applied Psychology, 90(2), 295-305.

Teerikangas, S. \& Joseph, R. J. (2012). Post-deal integration. An overview. In: David Faulkner, Satu Teerikangas and Richard J. Joseph (Eds.), The Handbook of Mergers and Acquisitions, pp. 339-371.

Thoits, P.A. (1989). The Sociology of Emotions. Annual Review of Sociology, 15, 317-342.

Tian, Y. A., Nicholson, J. D., Eklinder-Frick, \& Johanson, M. (in press). The interplay between social capital and international opportunities: A processual study of international 'take-off' episodes in Chinese SMEs. Industrial Marketing Management, $\mathrm{xx}(\mathrm{xx}), \mathrm{xx}-\mathrm{xx}$.

Tooby, J. \& Cosmides, L. (2008). The Evolutionary Psychology of the Emotions and Their Relationship to Internal Regulatory Variables. In M. Lewis, J.M. Haviland-Jones, \& L.F. Barrett (Eds.), Handbook of Emotions (pp. 114-137). New York: The Guildford Press. 
Van de Ven, A. (1992). Suggestions for studying strategy process: a research note. Strategic Management Journal, 13, Special Issue, 169-191.

Verduyn, P., Van Mechelen, I., Tuerlinckx, F., Meers, K., \& Van Coillie, H. (2009). Intensity profiles of emotional experience over time. Cognition and Emotion, 23(7), 1427-1443.

Vince, R. (2006). Being taken over: Managers' emotions and rationalizations during a company takeover. Journal of Management Studies, 43(2), 343-365.

Welch, C., Marschan-Piekkari, R., Penttinen, H. \& Tahvanainen, M. (2002). Corporate elites as informants in qualitative international business research. International Business Review, 11(5), 611-628.

World Investment Report (2017). Investment in the digital economy. United Nations Publications: United Nations, Geneva, Switzerland.

Yin, R.K. (2014). Case Study Research. Design and Methods (5th ed.). Sage Publications: Thousand Oaks.

Zagelmeyer, S., Sinkovics, R.R., Sinkovics, N., \& Kusstatscher, V. (2016). Exploring the link between management communication and emotions in mergers and acquisitions. Canadian Journal of Administrative Sciences, online DOI:10.1002/CJAS.1382.

Zeelenberg, M. \& Pieters, R. (2006). Feeling is for doing: A pragmatic approach to the study of emotions in economic behavior. In: D. De Cremer, M. Zeelenberg and K. Murnighan (Eds.). Social Psychology and Economics. Erlbaum: Mahwah, USA. 


\section{APPENDIX}

Table A.10 Example of interview questions

Interien' gutde, exomples of questions

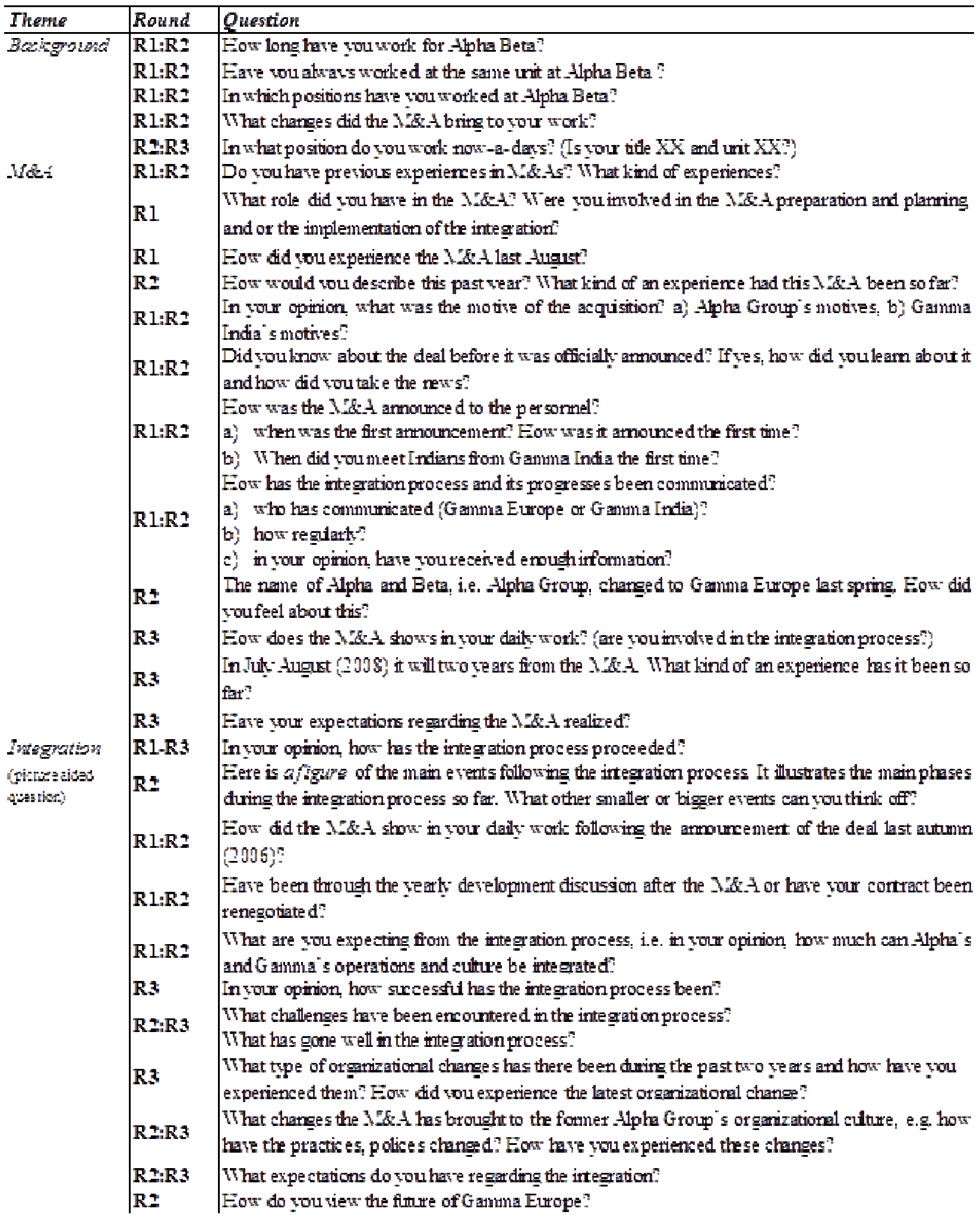


Table A.11 The position of the interviewees, interview times and modes

\begin{tabular}{|c|c|c|c|c|c|}
\hline $\begin{array}{l}\text { Interviewee/ Organizational } \\
\text { Position. }\end{array}$ & $\begin{array}{r}\text { Retention } \\
\text { contract }\end{array}$ & Turnover & $\begin{array}{l}\text { Face-to- } \\
\text { face }\end{array}$ & $\begin{array}{c}\text { Phone } \\
\text { interviews }\end{array}$ & Dates \\
\hline $\begin{array}{l}\text { CEO 2006-2007 } \\
\text { Busmess Development, CEO } \\
\text { Oct } 2007-.>\end{array}$ & $\frac{x}{x}$ & $\mathbf{x}$ & $\frac{\operatorname{six}}{\operatorname{mxx}}$ & $x$ & 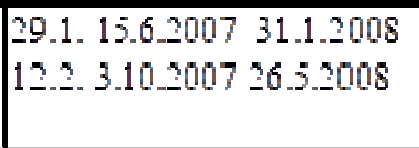 \\
\hline Director & & & & & \\
\hline Te chnologr Director & $x$ & $x$ & $5 x$ & & 29.1 .1 .10 .20073 .6 .2008 \\
\hline Support/World Wide Sales & & & & & \\
\hline $\begin{array}{l}\text { Account mathager } \\
\text { Account mannger } \\
\text { Senior A ccoung mathger }\end{array}$ & $x$ & & $\frac{5 x}{\mathrm{mx}}$ & $x$ & $\mid \begin{array}{ll}1.2 .1 .10 .2007 & 3.6 .2008 \\
8.2 .4 .10 .2007 & 11.6 .2008 \\
13.2 .23 .10 .2007 & 28.5008\end{array}$ \\
\hline Software & & & & & \\
\hline $\begin{array}{l}\text { Vice president Sofware } \\
\text { Senior Sofware Architect } \\
\text { Senor Sofvarte Archiect }\end{array}$ & $x$ & $\begin{array}{l}\mathrm{x} \\
\mathrm{x}\end{array}$ & $\begin{array}{l}\mathrm{mxx} \\
\mathrm{xx}\end{array}$ & $x$ & 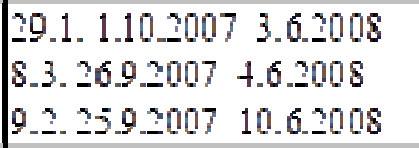 \\
\hline Handware & & & & & \\
\hline $\begin{array}{l}\text { Vice president Hardware } \\
\text { Engineer Manager } \\
\text { Engineer Mangger } \\
\text { Engineer Mangger }\end{array}$ & & & $\begin{array}{l}\operatorname{Ixx} \\
\operatorname{Ix} \\
\mathrm{xx} \\
\mathrm{xx}\end{array}$ & $x$ & $\mid \begin{array}{ll}12.3 .10 .2007 & 25.6 .2008 \\
12.2 .3 .102007 & 12.6 .2008 \\
12.2 .9 .10 .2007 & 24.6 .2008 \\
8.2 .3 .10 .2007 & 11.6 .2008\end{array}$ \\
\hline
\end{tabular}


Interviewee 3/ Former (and new) CEO, former minority shareholder

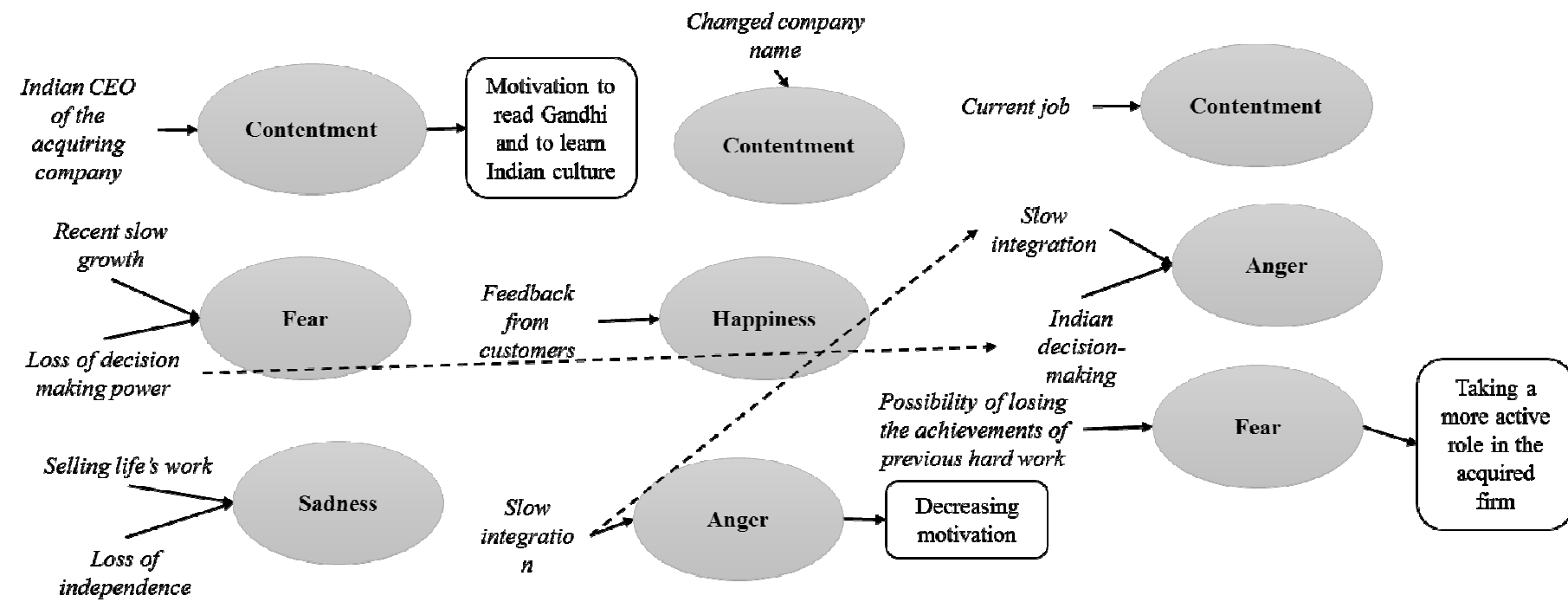

Time I

Time II

Time III

\section{Figure A.3 The emotional experience of Interviewee 3}

\section{Interviewee 5/ Account manager}

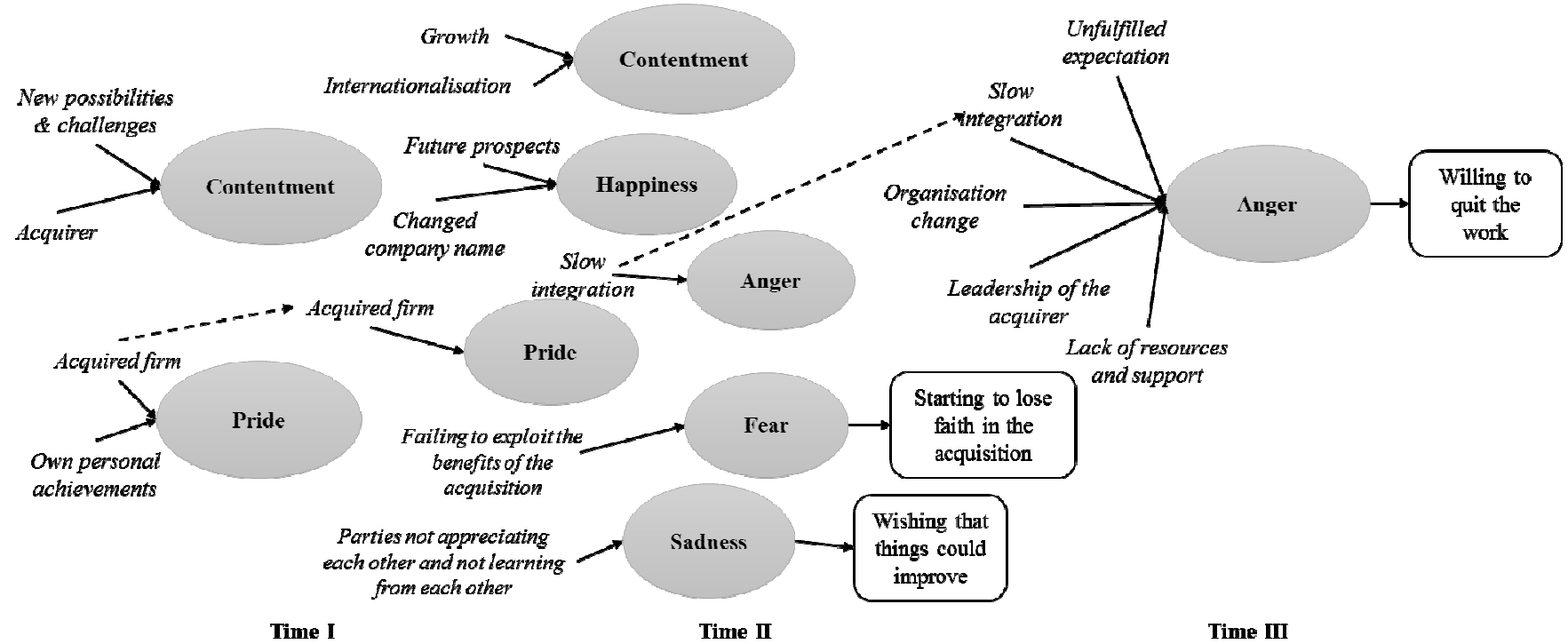

Figure A.4 The emotional experience of Interviewee 5 
Interviewee 9 / Technology Director, top manager and key person, former founder and shareholder

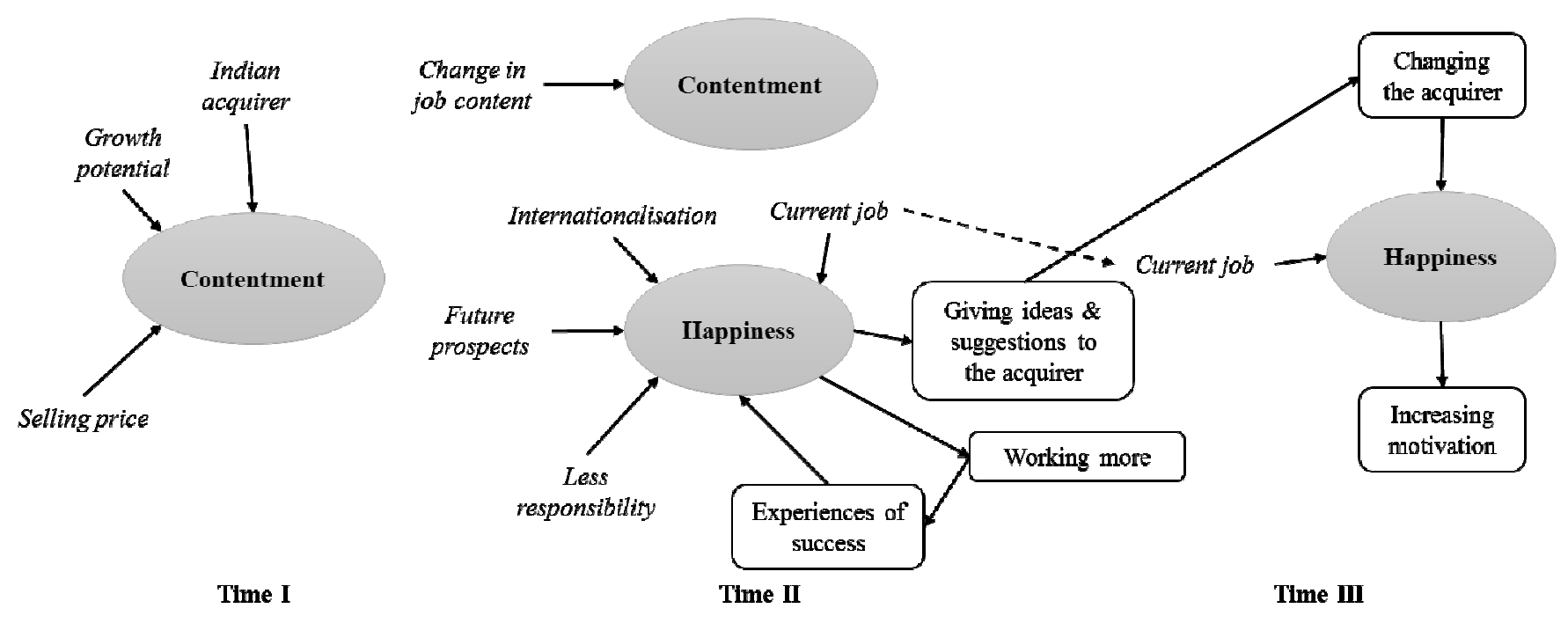

Figure A.5 Emotional experience of Interviewee 9

Intervicwec 10/ Account manager, former minority sharcholder

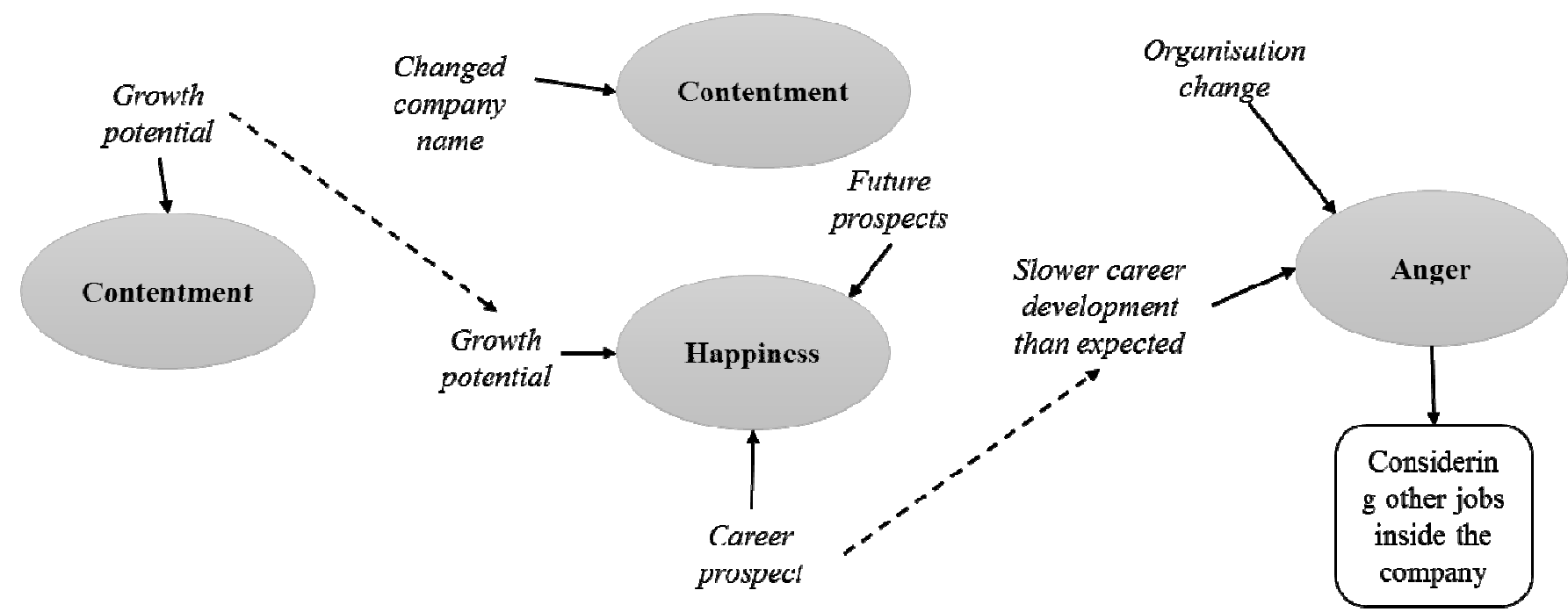

Time I

Time II

Time III

Figure A.6 Emotional experience of Interviewee 10 